\title{
Secondary organic aerosol formation from hydroxyl radical oxidation and ozonolysis of monoterpenes
}

\author{
D. F. Zhao ${ }^{1}$, M. Kaminski ${ }^{1}$, P. Schlag ${ }^{1}$, H. Fuchs ${ }^{1}$, I.-H. Acir ${ }^{1}$, B. Bohn ${ }^{1}$, R. Häseler ${ }^{1}$, A. Kiendler-Scharr ${ }^{1}$, F. Rohrer ${ }^{1}$, \\ R. Tillmann ${ }^{1}$, M. J. Wang ${ }^{1}$, R. Wegener ${ }^{1}$, J. Wildt ${ }^{2}$, A. Wahner ${ }^{1}$, and Th. F. Mentel ${ }^{1}$ \\ ${ }^{1}$ Institute of Energy and Climate Research, IEK-8: Troposphere, Forschungszentrum Jülich, 52425 Jülich, Germany \\ ${ }^{2}$ Institute of Bio- and Geosciences, IBG-2, Forschungszentrum Jülich, 52425 Jülich, Germany
}

Correspondence to: Th. F. Mentel (t.mentel@fz-juelich.de)

Received: 25 April 2014 - Published in Atmos. Chem. Phys. Discuss.: 16 May 2014

Revised: 1 October 2014 - Accepted: 15 December 2014 - Published: 28 January 2015

\begin{abstract}
Oxidation by hydroxyl radical $(\mathrm{OH})$ and ozonolysis are the two major pathways of daytime biogenic volatile organic compound (BVOC) oxidation and secondary organic aerosol (SOA) formation. In this study, we investigated the particle formation of several common monoterpenes $(\alpha-$ pinene, $\beta$-pinene and limonene) by $\mathrm{OH}$-dominated oxidation, which has seldom been investigated. $\mathrm{OH}$ oxidation experiments were carried out in the SAPHIR (Simulation of Atmospheric PHotochemistry In a large Reaction) chamber in Jülich, Germany, at low $\mathrm{NO}_{\mathrm{x}}(0.01 \sim 1 \mathrm{ppbV})$ and low ozone $\left(\mathrm{O}_{3}\right)$ concentration $(<20 \mathrm{ppbV})$. OH concentration and total $\mathrm{OH}$ reactivity $\left(k_{\mathrm{OH}}\right)$ were measured directly, and through this the overall reaction rate of total organics with $\mathrm{OH}$ in each reaction system was quantified. Multi-generation reaction process, particle growth, new particle formation (NPF), particle yield and chemical composition were analyzed and compared with that of monoterpene ozonolysis. Multi-generation products were found to be important in $\mathrm{OH}$-dominated SOA formation. The relative role of functionalization and fragmentation in the reaction process of $\mathrm{OH}$ oxidation was analyzed by examining the particle mass and the particle size as a function of $\mathrm{OH}$ dose. We developed a novel method which quantitatively links particle growth to the reaction rate of $\mathrm{OH}$ with total organics in a reaction system. This method was also used to analyze the evolution of functionalization and fragmentation of organics in the particle formation by $\mathrm{OH}$ oxidation. It shows that functionalization of organics was dominant in the beginning of the reaction (within two lifetimes of the monoterpene) and fragmentation started to play an important role after that. We compared particle formation from $\mathrm{OH}$ oxidation with that from pure ozonolysis. In indi-
\end{abstract}

vidual experiments, growth rates of the particle size did not necessarily correlate with the reaction rate of monoterpene with $\mathrm{OH}$ and $\mathrm{O}_{3}$. Comparing the size growth rates at the similar reaction rates of monoterpene with $\mathrm{OH}$ or $\mathrm{O}_{3}$ indicates that, generally, $\mathrm{OH}$ oxidation and ozonolysis had similar efficiency in particle growth. The SOA yield of $\alpha$-pinene and limonene by ozonolysis was higher than that of $\mathrm{OH}$ oxidation. Aerosol mass spectrometry (AMS) shows SOA elemental composition from $\mathrm{OH}$ oxidation follows a slope shallower than -1 in the $\mathrm{O} / \mathrm{C}$ vs. $\mathrm{H} / \mathrm{C}$ diagram, also known as Van Krevelen diagram, indicating that oxidation proceeds without significant loss of hydrogen. SOA from $\mathrm{OH}$ oxidation had higher $\mathrm{H} / \mathrm{C}$ ratios than SOA from ozonolysis. In ozonolysis, a process with significant hydrogen loss seemed to play an important role in SOA formation.

\section{Introduction}

As an important class of atmospheric aerosol, organic aerosol (OA) comprises a significant fraction of aerosol mass. It accounts for around $50 \%$ of dry tropospheric submicron aerosol mass in many urban and rural locations (Kanakidou et al., 2005; Jimenez et al., 2009; Zhang et al., 2011). OA has an strong impact on air pollution, human health and climate on the regional and global scale. A large fraction of organic aerosol is contributed by secondary organic aerosol (SOA). In spite of intensive studies in recent years, the source of SOA still has considerable uncertainties with the estimated global source ranging from 120 to $1820 \mathrm{Tg} \mathrm{a}^{-1}$ (Hallquist et al., 2009; Spracklen et al., 2011; Goldstein and Galbally, 
2007). SOA is believed to mainly originate from the biogenic volatile organic compounds (BVOCs) from plants (Hallquist et al., 2009). Among them, monoterpenes are important due to their high emission rates and high reactivity (Chung and Seinfeld, 2002; Guenther et al., 1995, 2012).

The impact of SOA on the radiation budget of the Earth thus depends on its particle number concentration, size distribution and composition, which affect optical properties and cloud condensation nuclei (CCN) activity of an aerosol (Andreae and Rosenfeld, 2008). Understanding particle formation and growth is therefore critical for assessing the impact of SOA.

Particle formation and growth from BVOCs are mainly initiated by hydroxyl radical $(\mathrm{OH})$ and ozone $\left(\mathrm{O}_{3}\right)$ oxidation during daytime. SOA formation from ozonolysis of several monoterpenes such as $\alpha$-pinene, $\beta$-pinene and limonene has been studied extensively (Iinuma et al., 2005; Presto et al., 2005; Shilling et al., 2009; Yu et al., 1999; Ortega et al., 2012; Saathoff et al., 2009; Tillmann et al., 2010; Hoffmann et al., 1997; Griffin et al., 1999; Lee et al., 2006; Ma et al., 2008). However, particle formation from $\mathrm{OH}$ oxidation of monoterpenes has been much less investigated and pure $\mathrm{OH}$ oxidation of monoterpenes has seldom been investigated due to the presence of $\mathrm{O}_{3}$ formed in the photooxidation process (Eddingsaas et al., 2012; Ng et al., 2007; Lee et al., 2006). SOA formation from pure $\mathrm{OH}$ oxidation of monoterpenes regarding the reaction process, such as the formation and role of multi-generation products, and the influence of $\mathrm{OH}$ oxidation on particle growth is not clear. Particularly, despite the importance of the $\mathrm{OH}$ oxidation in the particle formation, the quantitative effect of $\mathrm{OH}$ oxidation on particle growth is not available. Here we focus on the SOA formation from $\mathrm{OH}$ oxidation of monoterpenes.

It is also interesting to compare the relative importance of $\mathrm{OH}$ oxidation with ozonolysis of monoterpenes in particle nucleation and growth. A number of studies have investigated this question (Bonn and Moortgat, 2002; Burkholder et al., 2007; Hao et al., 2009; Mentel et al., 2009), but often at high VOC concentrations and the results are controversial. Some studies have shown the importance of ozonolysis in new particle formation (NPF) (Bonn and Moortgat, 2002), while others have emphasized the importance of $\mathrm{OH}$ oxidation (Burkholder et al., 2007; Hao et al., 2009; Mentel et al., 2009). Studies at the simulation chamber JPAC (Jülich Plant Aerosol Atmosphere Chamber) suggest $\mathrm{OH}$ and $\mathrm{H}_{2} \mathrm{SO}_{4}$ are needed to initiate NPF (Mentel et al., 2009; Kiendler-Scharr et al., 2009a, 2012; Ehn et al., 2014). Ehn et al. (2014) suggest that $\alpha$-pinene ozonolysis produces a class of extreme low volatile organic compounds (ELVOC), a recently discovered highly oxidized multifunctional products, which are important for the nucleation and possibly make up 50-100\% of SOA in early stages of particle growth in Hyytiälä (Ehn et al., 2012). Regarding particle growth, Burkholder et al. (2007) stated that particle size growth rates for different oxidation sources are nearly indistinguishable. Yet, Hao et al. (2009), using the real BVOC emissions from plants, showed a much more efficient role of ozonolysis than $\mathrm{OH}$ oxidation in particle growth. One reason causing the different results on nucleation could be that VOC oxidation products are not the nucleating agents. Another important reason for the controversy on particle nucleation and growth is that the $\mathrm{OH}$ oxidation and ozonolysis have seldom been separated when comparing the SOA formation from both pathways.

In addition, the reaction rates of $\mathrm{OH}$ and $\mathrm{O}_{3}$ with organics have to be quantified and comparable when one investigates the relative role of $\mathrm{OH}$ oxidation and ozonolysis in particle formation. To obtain the reaction rates of VOCs with $\mathrm{OH}$, the $\mathrm{OH}$ concentration is a required parameter. However, none of these previous studies directly measured the $\mathrm{OH}$ concentration, which was either not stated or just modeled. Since the detailed chemistry, including $\mathrm{HO}_{\mathrm{x}}$ generation pathways, of BVOC photooxidation is still not well understood, modeled $\mathrm{OH}$ concentrations may have significant uncertainties (Fuchs et al., 2013; Kaminiski, 2014; Kim et al., 2013; Whalley et al., 2011). Consequently, the relative importance of $\mathrm{OH}$ oxidation and ozonolysis in particle formation and growth may have large uncertainties when the comparison of both cases is based on modeled $\mathrm{OH}$ concentrations and corresponding reaction rates with $\mathrm{OH}$.

In this study, we investigated the SOA formation and growth of several common monoterpenes, $\alpha$-pinene, $\beta$ pinene and limonene, by $\mathrm{OH}$ oxidation at ambient relevant conditions low $\mathrm{NO}_{\mathrm{x}}(0.01-1 \mathrm{ppbV})$, low VOCs $(\sim 4 \mathrm{ppbV})$ and low particle concentrations (sub- $\mu \mathrm{g} \mathrm{m}^{-3}$ to several $\mu \mathrm{g} \mathrm{m}^{-3}$ ). The $\mathrm{OH}$ oxidation experiments were conducted at low $\mathrm{O}_{3}$ concentration $(<20 \mathrm{ppbV})$ to ensure that $\mathrm{OH}$ oxidation was the dominant reaction pathway. $\mathrm{OH}$ concentration was measured directly, as was the total reactivity $\left(k_{\mathrm{OH}}\right)$ of the whole reaction system with respect to $\mathrm{OH}$, so that the overall reaction rates of organics with $\mathrm{OH}$ were directly quantified (Lou et al., 2010). Note that $k_{\mathrm{OH}}$ denotes $\mathrm{OH}$ reactivity throughout this paper rather than the rate constant for the reaction of individual species with $\mathrm{OH}$. Direct derivation of the overall reaction rate of total organics with $\mathrm{OH}$ (product of $\mathrm{OH}$ reactivity of total organics and the $\mathrm{OH}$ concentration) from measured parameters is a unique feature of this study. The multi-generation reaction process, particle growth, NPF, particle yield and particle composition were analyzed. A novel method which quantitatively established the relationship of particle mass growth rate with the reaction rate with $\mathrm{OH}$ was developed for the first time here to the best of our knowledge. This method was further used to analyze the multi-generation reaction process. Particle formation by $\mathrm{OH}$ oxidation was compared with that by ozonolysis. Ozonolysis experiments were done in the presence of $\mathrm{CO}$ as $\mathrm{OH}$ scavenger, so that ozonolysis was the dominant reaction pathway. Compared with other $\mathrm{OH}$ scavengers, mainly organics such as butanol, cyclohexane, etc., $\mathrm{CO}$ helps keep the $\mathrm{RO}_{2} / \mathrm{HO}_{2}$ concentration low since in the atmosphere $\mathrm{HO}_{2}$ usually exceeds or is close to $\mathrm{RO}_{2}$ concentration (Hanke et 
al., 2002; Mihelcic et al., 2003), in contrast with many laboratory studies where $\mathrm{RO}_{2}$ concentration is much higher than $\mathrm{HO}_{2}$ concentration (Kroll and Seinfeld, 2008). The relative roles of $\mathrm{OH}$ oxidation and ozonolysis in SOA formation and particle growth were evaluated from comparisons of $\mathrm{OH}$ and $\mathrm{O}_{3}$-dominated experiments. In particular, we used low VOC concentration $(\sim 4 \mathrm{ppb})$ with natural sunlight conditions resulting in low particle loading (sub- $\mu \mathrm{g} \mathrm{m}^{-3}$ to several $\mu \mathrm{g} \mathrm{m}^{-3}$ ). The low particle loading allowed us to investigate the particle formation, particle growth and multi-generation reaction process under ambient relevant conditions (Presto and Donahue, 2006; Shilling et al., 2008, 2009; Pathak et al., 2007). It also minimized the condensation of early generation products with low oxidation state which is of little relevance for ambient conditions (Shilling et al., 2009; Pfaffenberger et al., 2013).

\section{Experimental}

\subsection{Experiment setup and instrumentation}

The experiments were carried out in the outdoor atmosphere simulation chamber SAPHIR (Simulation of Atmospheric PHotochemistry In a large Reaction chamber), Forschungszentrum Jülich, Germany. SAPHIR is a $270 \mathrm{~m}^{3}$ double-wall Teflon chamber of cylindrical shape. The details of the chamber have been previously described (Rohrer et al., 2005; Bohn et al., 2005). The chamber uses natural sunlight as the light source and is equipped with a louvre system to simulate dark processes when the louvre is closed. It is operated with high purity synthetic air (Linde LiPur, purity $99.9999 \%$ ). A continuous flow of $7-9 \mathrm{~m}^{3} \mathrm{~h}^{-1}$ maintains the chamber at a slight overpressure of $\sim 50 \mathrm{~Pa}$ and compensates for the sampling losses by various instruments. This flow causes dilution of the reaction mixture with clean air at an average loss rate coefficient of $9.35 \times 10^{-6} \mathrm{~s}^{-1}$ (residence time of $\sim 30 \mathrm{~h}$ ), agreeing well with the dilution rates determined from measured $\mathrm{H}_{2} \mathrm{O}$ and $\mathrm{CO}_{2}$ time series. Pure nitrogen (Linde LiPur, purity $99.9999 \%$ ) constantly flushes the space between the inner and outer Teflon wall to prevent intrusion of contaminants into the chamber. A fan ensures mixing of trace gases within minutes, but reduces aerosol lifetime when it runs. The loss by dilution alone applies equally to suspended particles and gases.

For the experiments described here, the chamber was equipped with instrumentation characterizing gas-phase and particle-phase species as well as physical parameters including temperature, relative humidity, flow rate and photolysis frequencies.

The actinic flux and the according photolysis frequencies were provided from measurements of a spectral radiometer (Bohn et al., 2005). $\mathrm{NO}$ and $\mathrm{NO}_{2}$ measurements were performed with a chemiluminescence analyzer (ECO PHYSICS TR480) equipped with a photolytic converter
(ECO PHYSICS PLC760). For a time resolution of $90 \mathrm{~s}$ the detection limits of the $\mathrm{NO}_{\mathrm{x}}$ analyzer were 5 and $10 \mathrm{pptV}$ and the accuracies 5 and $10 \%$ for $\mathrm{NO}$ and $\mathrm{NO}_{2}$, respectively. $\mathrm{O}_{3}$ was measured by an UV absorption spectrometer (ANSYCO model O341M).

The concentrations of the VOCs were measured by a proton transfer reaction-mass spectrometer (PTR-MS, Ionicon) (Jordan et al., 2009) and gas chromatography coupled to a mass spectrometer (GC-MS, Agilent) (Apel et al., 2008; Kaminiski, 2014). From the measured monoterpene time series (shown in Fig. S3 in the Supplement), the timedependent monoterpene consumed during an experiment is obtained. The measured monoterpene consumed also agrees with that calculated from the initial concentration and loss by the reaction with $\mathrm{OH}$ and dilution within the uncertainty of measurement (PTR-MS: $\pm 15 \%, \mathrm{OH}$ concentration: $\pm 10 \%$ ) and the reaction rate constant of monoterpene (Atkinson et al., 2006; Atkinson and Arey, 2003; Gill and Hites, 2002) as shown in Fig. S6. In the ozonolysis experiments, reactions of VOCs with $\mathrm{O}_{3}$ in the sample line were found to cause additional monoterpene loss. Monoterpene concentrations were therefore also quantified from initial monoterpene concentrations and the losses by reaction according to the reaction rate of $\mathrm{O}_{3}$ with monoterpenes determined from measured $\mathrm{O}_{3}$ and by dilution.

$\mathrm{OH}, \mathrm{HO}_{2}$ and $\mathrm{RO}_{2}$ radicals were measured using laserinduced fluorescence (LIF). The uncertainty of the $\mathrm{OH}$ measurement, determined by the accuracy of the calibration of the LIF instrument, is $10 \%(1 \sigma)$. The details of LIF instrument were described by Fuchs et al. (2012). The OH radicals inside SAPHIR are mainly formed by the photolysis of HONO (nitrous acid) directly coming off the chamber walls through a photolytic process, and to a minor fraction by $\mathrm{O}_{3}$ photolysis (Rohrer et al., 2005). No additional OH generator was used.

Total $\mathrm{OH}$ reactivity $\left(k_{\mathrm{OH}}\right)$, which is equivalent to the inverse atmospheric $\mathrm{OH}$ lifetime, was measured also using flash photolysis/laser-induced fluorescence (FP/LIF) technique that was first realized by Calpini et al. (1999) and later by Sadanaga et al. (2004). $k_{\mathrm{OH}}$ is a pseudo-first-order rate constant, equal to the sum of products of the concentrations of all species reacting with $\mathrm{OH}$ with their rate constants. Laser flash photolysis (LFP) of ozone is used to produce $\mathrm{OH}$ in a sample of air and LIF is applied to monitor the time-dependent $\mathrm{OH}$ decay. From the time-dependent $\mathrm{OH}$ decay the $k_{\mathrm{OH}}$ was obtained. The instrument used in this work at SAPHIR was deployed in previous field campaigns and is described in detail elsewhere (Hofzumahaus et al., 2009; Lou et al., 2010).

The $\mathrm{OH}$ concentration was used to calculate the $\mathrm{OH}$ dose in order to better compare different experiments. The $\mathrm{OH}$ dose is the integral of the $\mathrm{OH}$ concentration over time and gives the cumulated $\mathrm{OH}$ concentrations to which gases and particles were exposed at a given time of an experiment. One hour exposure to typical atmospheric $\mathrm{OH}$ concentrations of 
$2 \times 10^{6}$ molecules $\mathrm{cm}^{-3}$ results in an $\mathrm{OH}$ dose of $7.2 \times$ $10^{9}$ molecules $\mathrm{cm}^{-3} \mathrm{~s}$. The $\mathrm{OH}$ concentration and $\mathrm{OH}$ reactivity were also used to calculate the reaction rate of $\mathrm{OH}$ with total organics.

Particle size distributions were measured by a scanning mobility particle sizer (SMPS, TSI DMA3081/TSI CPC 3785) with a size range $9.82-414.2 \mathrm{~nm}$. Aerosol yield was calculated using SMPS mass concentration assuming a density of $1 \mathrm{~g} \mathrm{~cm}^{-3}$ to compare with previous studies in the literature. Aerosol density is assumed to be constant throughout one experiment, since from our previous studies the density was found to be relatively constant throughout the whole experiment (Salo et al., 2011; Saathoff et al., 2009). Particles in the chamber are subject to wall losses as reported previously (Salo et al., 2011; Fry et al., 2011). Size effects of the particle loss were neglected here because of the narrow size distribution (geometric standard deviation < 1.3). In this study, the particle wall-loss rate was determined using an exponential fit of the decay of the particle number concentration after the nucleation has stopped for several hours (Carter et al., 2005; Fry et al., 2011; Pierce et al., 2008). In addition to particle wall loss, vapor wall losses to the wall have been observed in the laboratory chamber studies (Matsunaga and Ziemann, 2010; Zhang et al., 2014). The particle mass concentration corrected for dilution and wall loss is shown here unless otherwise stated. Vapor wall losses were not corrected here due to the difficulty to quantify, but the effect of vapor loss on the particle mass concentration is discussed. The uncertainty of the particle mass concentration, due to uncertainty of the particle wall loss and vapor wall loss is also discussed.

The chemical composition of SOA was characterized by a high-resolution time-of-flight aerosol mass spectrometer (HR-ToF-AMS, Aerodyne Research Inc., DeCarlo et al., 2006). Particles enter the instrument through an aerodynamic lens and are focused to a particle beam. The particles impact on a tungsten oven at $600^{\circ} \mathrm{C}$ and are flash vaporized into vapors under vacuum. The vapors are then ionized by $70 \mathrm{eV}$ electron impact (EI), and the resulting ions are detected by a time-of-flight mass spectrometer operating at either a highsensitivity mode ( $\mathrm{V}$-mode) or a high mass resolution mode (W-mode). In this study we used the so-called MS (mass spectrum) mode which gets the size integrated overall composition of SOA.

To characterize the degree of oxidation of particles, the $\mathrm{O} / \mathrm{C}$ ratio was obtained. The $\mathrm{O} / \mathrm{C}$ and $\mathrm{H} / \mathrm{C}$ ratios, also known as Van Krevelen diagram, were derived by the elemental analysis of mass spectra obtained in the high mass resolution W-mode as described by Aiken et al. $(2007,2008)$. An updated procedure to calculate $\mathrm{O} / \mathrm{C}$ and $\mathrm{H} / \mathrm{C}$ was reported to be in development (Canagaratna et al., 2015). However, the details have not been published yet; therefore, the traditional method is still used here to derive the elemental ratio. Corrections for the minor influence of gaseous components were done before the calculation of the $\mathrm{H} / \mathrm{C}$ and $\mathrm{O} / \mathrm{C}$ ratios. Chamber air contains $\mathrm{CO}_{2}$ and water vapor and both gas-phase species contribute to the mass spectra. The contribution of gas-phase $\mathrm{CO}_{2}$ and water vapor to $\mathrm{m} / \mathrm{z}$ (massto-charge ratio) 44 and to $m / z 18$, respectively, was inferred from measurements during periods when no particles were present. The values were subtracted to obtain the particle signals before the elemental analysis (Allan et al., 2004). No collection efficiency correction was further used.

\subsection{Experiment procedure}

Two kinds of experiments, photooxidation and ozonolysis of monoterpenes were carried out under humid conditions with a starting $\mathrm{RH} \sim 75 \%$. The summary of the experimental conditions is shown in Table 1. All the experiments were conducted under $\mathrm{NO}_{\mathrm{x}}<\sim 1 \mathrm{ppb}$. No $\mathrm{NO}_{\mathrm{x}}$ was added to the chamber, and background $\mathrm{NO}_{\mathrm{x}}$ originated mainly from the wall. In the photooxidation experiments, the $\mathrm{O}_{3}$ concentration was $<3 \mathrm{ppb}$ at the start of each experiment and did not exceed $20 \mathrm{ppb}$ over the course of an experiment. The $\mathrm{OH}$ oxidation was the dominant oxidation pathway ( $>\sim 95 \%$ of monoterpene loss). In a typical procedure, air in the chamber was first humidified and then the louvre system was opened for around $1.5 \mathrm{~h}$. Afterwards monoterpene was injected and the reaction of monoterpene with $\mathrm{OH}$ occurred. After the photooxidation process, which was finished by closing the louvre system, the reaction mixtures stayed in the dark for around $1 \mathrm{~h}$ before they were flushed out. Before nucleation there were some background particles present introduced after humidification which had relatively large diameter (median diameter 40-60 nm) but with fairly low concentration (refer to Table 1). Particle size before nucleation was not shown in order to avoid confusion. The ozonolysis experiments were conducted in the dark. After humidification $\mathrm{CO}$ and monoterpene were added to the chamber. $\mathrm{CO}$ $(\sim 40 \mathrm{ppm})$ was used as $\mathrm{OH}$ scavenger to ensure that oxidation by $\mathrm{O}_{3}$ was the dominant reaction pathway ( $>95 \%$ of $\mathrm{OH}$ was scavenged) with little contribution of the $\mathrm{OH}$ oxidation to monoterpenes losses. Afterwards, $\mathrm{O}_{3}$ generated from an $\mathrm{UV} \mathrm{O}_{3}$ generator was added to the chamber to start ozonolysis reaction of monoterpenes.

\section{Methods}

In the reaction of monoterpenes with $\mathrm{OH}$ and $\mathrm{O}_{3}$, oxidation products are generated, which condense on the particle phase resulting in particle growth. In the case of $\mathrm{OH}$ oxidation, multi-generation products can be formed from the further reaction of first generation products with $\mathrm{OH}$, while for the ozonolysis of monoterpenes, with one carbon-carbon double bond, the reaction products do not react with $\mathrm{O}_{3}$ any more since the double carbon bond has been broken down. Particle growth depends on the condensation flux, and thus the concentration of condensing products, of all generations. Since 
Table 1. Summary of experimental conditions. All experiments were performed at initial $\mathrm{RH} 75 \%$ and $\mathrm{NO}_{\mathrm{x}}<1 \mathrm{ppb}$.

\begin{tabular}{|c|c|c|c|c|c|c|c|}
\hline $\begin{array}{l}\text { Experiment } \\
\text { type }\end{array}$ & $\begin{array}{l}\text { VOC } \\
\text { type }\end{array}$ & $\begin{array}{l}\text { VOC initial } \\
(\mathrm{ppb})\end{array}$ & $\begin{array}{l}{[\mathrm{OH}]} \\
\left(10^{6} \text { molecules } \mathrm{cm}^{-3}\right)\end{array}$ & $\begin{array}{r}\text { Initial } \mathrm{O}_{3} \\
(\mathrm{ppb})\end{array}$ & Average $T(\mathrm{~K})$ & $\begin{array}{r}\text { Initial mass } \\
\left(\mu \mathrm{g} \mathrm{m}^{-3}\right)\end{array}$ & $\begin{array}{r}\text { Rate coefficient } \\
\left(\text { molecule }{ }^{-1} \mathrm{~cm}^{3} \mathrm{~s}^{-1}\right)^{\mathrm{b}}\end{array}$ \\
\hline \multirow[t]{3}{*}{$\mathrm{OH}$ oxidation } & $\alpha$-pinene & 4 & 6.4 & 1.0 & 299 & $6.1 \times 10^{-3}$ & $5.25 \times 10^{-11}$ \\
\hline & $\beta$-pinene & 4 & 6.2 & 2.5 & 301 & $9.5 \times 10^{-3}$ & $7.89 \times 10^{-11}$ \\
\hline & limonene & 4 & 6.4 & 2.2 & 298 & $12.2 \times 10^{-3}$ & $1.64 \times 10^{-11}$ \\
\hline \multirow[t]{3}{*}{ Ozonolysis } & $\alpha$-pinene & 4 & $\mathrm{NDs}^{\mathrm{a}}$ & 136 & 289 & $9.2 \times 10^{-3}$ & $8.72 \times 10^{-16}$ \\
\hline & $\beta$-pinene & 4 & NDs & 760 & 294 & $5.7 \times 10^{-3}$ & $1.50 \times 10^{-16}$ \\
\hline & limonene & 4 & NDs & 136 & 290 & $11.7 \times 10^{-3}$ & $2.08 \times 10^{-16}$ \\
\hline
\end{tabular}

${ }^{\mathrm{a}}$ Below the detection limit of instruments $\left(0.3 \times 10^{6}\right.$ molecules $\left.\mathrm{cm}^{-3}\right) .{ }^{\mathrm{b}}$ Atkinson and Arey (2003).

the concentration of condensing products is a function of the reaction rate, particle growth is closely related to the reaction rate of organics. We explored the relationship between particle mass growth and reaction rate of the organics with $\mathrm{OH}$. When particles grow, the particle diameter enlarges and the particle mass increases due to the condensation of the reaction products. Here we use the term particle size growth rate to denote the particle diameter increase and mass growth rate to denote the particle mass increases. In the following we will establish a quantitative relationship of the particle mass growth rate with the reaction rate of $\mathrm{OH}$ with total organics for the first time, to the best of our knowledge. Since all condensing species contribute to the particle mass growth rate, the particle mass growth rate must be related to the reaction rate of total organic species with $\mathrm{OH}$, which is directly accessible from the $\mathrm{OH}$ concentration measurement and the $k_{\mathrm{OH}}$ measurement in this study. The particle mass growth rate is derived from the sum of the particle mass growth due to all condensing compounds.

In a first step, we will relate the overall mass growth to the $\mathrm{OH}$ gas-phase reaction rates with total organic species. We describe this with a reaction of $\mathrm{VOC} i$ with $\mathrm{OH}$, in which for simplicity one molecule of species $i$ reacts with $\mathrm{OH}$, forming one molecule of species $i+$ of the next generation:

$i+\mathrm{OH} \longrightarrow i+$.

According to the Raoult's law we have the following equation, assuming the gas phase and particle phase are in equilibrium:

$C_{i}^{\mathrm{g}}=\frac{C_{i}^{\mathrm{p}}}{C_{\mathrm{t}}^{\mathrm{p}}} \cdot C_{i}^{0}$,

where $C_{i}^{\mathrm{g}}$ and $C_{i}^{\mathrm{p}}$ are the concentrations of $i$ in the gas phase and in the particle phase (molecules $\mathrm{cm}^{-3}$ ), respectively, $C_{i}^{0}$ is the saturation vapor pressure of $i$ expressed as gas-phase concentration of $i$ (molecules $\mathrm{cm}^{-3}$ ) and $C_{\mathrm{t}}^{\mathrm{p}}$ is the concentration of all molecules in the particle phase; thus, $C_{i}^{\mathrm{p}} / C_{\mathrm{t}}^{\mathrm{p}}$ is the mole fraction of $i$. For high-volatility species, $C_{i}^{0}$ is high for given $C_{i}^{\mathrm{g}}$ and thus $C_{i}^{\mathrm{p}}$ is low or even negligible. The opposite is true for low volatility species, $C_{i}^{0}$ is low and $C_{i}^{\mathrm{p}}$ is high.
When an infinitesimal concentration of $i, \mathrm{~d} C_{i}^{\mathrm{g}}$, reacts via Reaction (R1), corresponding to a change of $i$ in the particle phase, $\mathrm{d} C_{i}^{\mathrm{p}}$, from Eq. (1), one can get Eq. (2). $C_{\mathrm{t}}^{\mathrm{p}}$ is assumed to be constant in each time step because the change in each time step is minor compared to $C_{\mathrm{t}}^{\mathrm{p}}$; furthermore, loss of $i$ is compensated for by a gain in $i+$ when the vapor pressure of $i+$ is sufficiently low to be on the particle phase and thus $C_{\mathrm{t}}^{\mathrm{p}}$ is approximately conserved.

$\mathrm{d} C_{i}^{\mathrm{g}}=\frac{\mathrm{d} C_{i}^{\mathrm{p}}}{C_{\mathrm{t}}^{\mathrm{p}}} \cdot C_{i}^{0}$

Re-arranging Eq. (2), one can get

$\mathrm{d} C_{i}^{\mathrm{p}}=\frac{C_{\mathrm{t}}^{\mathrm{p}}}{C_{i}^{0}} \cdot \mathrm{d} C_{i}^{\mathrm{g}}$.

Similarly, one can get

$\mathrm{d} C_{i+1}^{\mathrm{p}}=\frac{C_{\mathrm{t}}^{\mathrm{p}}}{C_{i+1}^{0}} \cdot \mathrm{d} C_{i+1}^{\mathrm{g}}$.

For the change in the particle mass concentration (m, $\mu \mathrm{g} \mathrm{m}^{-3}$ ) due to the reaction of species $i$ by Reaction (R1), we have

$\left(\frac{\mathrm{d} m}{\mathrm{~d} t}\right)_{i}=\frac{\mathrm{d} m_{i+}^{\mathrm{p}}}{\mathrm{d} t}+\frac{\mathrm{d} m_{i}^{\mathrm{p}}}{\mathrm{d} t}$.

$\mathrm{d} m_{i}^{\mathrm{p}}\left(\mu \mathrm{g} \mathrm{m}^{-3}\right)$ and $\mathrm{d} C_{i}^{\mathrm{p}}$ can be related by

$\mathrm{d} m_{i}^{\mathrm{p}}=\frac{\mathrm{d} C_{i}^{\mathrm{p}} \cdot M_{i} \cdot 10^{6} \cdot 10^{6}}{N_{\mathrm{A}}}$,

where $M_{i}$ is the molecular weight of species $i\left(\mathrm{~mol} \mathrm{~kg}^{-1}\right)$ and $N_{\mathrm{A}}$ is Avogadro's constant.

Similarly with Eq. (6), for species $i+$, one can get

$\mathrm{d} m_{i+}^{\mathrm{p}}=\frac{\mathrm{d} C_{i+}^{\mathrm{p}} \cdot M_{i+} \cdot 10^{6} \cdot 10^{6}}{N_{\mathrm{A}}}$.

By applying the relationship of $i$ and $i+$ in the Reaction (R1), we express

$\mathrm{d} C_{i+}^{\mathrm{g}}=-\mathrm{d} C_{i}^{\mathrm{g}}$. 
Substituting Eqs. (3), (4), (6)-(8) into Eq. (5), one can get

$$
\left(\frac{\mathrm{d} m}{\mathrm{~d} t}\right)_{i}=\frac{\mathrm{d} C_{i}^{\mathrm{g}}}{\mathrm{d} t} \cdot C_{\mathrm{t}}^{\mathrm{p}} \frac{10^{6} \cdot 10^{6}}{N_{\mathrm{A}}}\left(\frac{M_{i}}{C_{i}^{0}}-\frac{M_{i+}}{C_{i+}^{0}}\right) .
$$

Assuming $M_{i+}$ and $M_{i}$ are similar, with an average molecular weight $M$, one can get

$m_{\mathrm{t}}=C_{\mathrm{t}}^{\mathrm{p}} \frac{10^{6} \cdot 10^{6}}{N_{\mathrm{A}}} M$,

where $m_{\mathrm{t}}$ is total particle mass concentration.

Substituting Eq. (10) into Eq. (9), one can get

$$
\left(\frac{\mathrm{d} m}{\mathrm{~d} t}\right)_{i}=\frac{\mathrm{d} C_{i}^{\mathrm{g}}}{\mathrm{d} t} \cdot m_{\mathrm{t}}\left(\frac{1}{C_{i}^{0}}-\frac{1}{C_{i+}^{0}}\right) .
$$

If we relax our assumption that one molecule of $i+$ is formed from the loss of one molecule of $i$ in Reaction (R1), e.g., in case of fragmentation, Eq. (11) still holds (as shown in Appendix A).

According to the reaction of $i$ with $\mathrm{OH}$, we have

$$
\frac{\mathrm{d} C_{i}^{\mathrm{g}}}{\mathrm{d} t}=-R_{\mathrm{OH}, i},
$$

where $R_{\mathrm{OH}, i}$ is the reaction rate of species $i$ with $\mathrm{OH}$.

Substitute Eq. (12) into Eq. (11) and one can get

$$
\left(\frac{\mathrm{d} m}{\mathrm{~d} t}\right)_{i}=R_{\mathrm{OH}, i} \cdot m_{\mathrm{t}}\left(\frac{1}{C_{i+}^{0}}-\frac{1}{C_{i}^{0}}\right) .
$$

Considering all the species contributing to the particle phase, we have

$$
\frac{\mathrm{d} m_{\mathrm{t}}}{\mathrm{d} t}=\sum_{i} R_{\mathrm{OH}, i} m_{\mathrm{t}}\left(\frac{1}{C_{i+}^{0}}-\frac{1}{C_{i}^{0}}\right) .
$$

Re-arrange Eq. (14) and

$$
\frac{\mathrm{d} m_{\mathrm{t}}}{\mathrm{d} t}=m_{\mathrm{t}} \sum_{i} R_{\mathrm{OH}, i} \frac{\sum_{i=1} R_{\mathrm{OH}, i}\left(\frac{1}{C_{i+}^{0}}-\frac{1}{C_{i}^{0}}\right)}{\sum_{i}^{R_{\mathrm{OH}, i}}} .
$$

Summing up all the species, we have

$$
R_{\mathrm{OH}}=\sum_{i}^{R_{\mathrm{OH}, i}}
$$

wherein $R_{\mathrm{OH}}$ is the reaction rate of total organics with $\mathrm{OH}$.

In the next step, we will derive a system characterizing quantity in order to overcome the underdetermined knowledge about the individual components due to the complexity of monoterpene degradation. We define a new metric,
$\mathrm{GE}_{\mathrm{OH}}(t, i)$ (particle growth efficiency with respect to the reaction of $\mathrm{OH}$ with total organics in the whole reaction system, including the VOCs and their oxidation products) in Eq. (17) for species $i$ :

$\mathrm{GE}_{\mathrm{OH}}(t, i)=\frac{1}{C_{i+}^{0}}-\frac{1}{C_{i}^{0}}$.

One can also define

$$
\frac{\sum_{i} R_{\mathrm{OH}, i} \cdot \frac{1}{C_{i+}^{0}}}{\sum_{i}^{R_{\mathrm{OH}, i}}}=\frac{1}{\bar{C}_{i+}^{0}},
$$

and

$\frac{\sum_{i} R_{\mathrm{OH}, i} \cdot \frac{1}{C_{i}^{0}}}{\sum_{i}^{R_{\mathrm{OH}, i}}}=\frac{1}{\bar{C}_{i}^{0}}$.

$\bar{C}_{i+}^{0}$ and $\bar{C}_{i}^{0}$ are obtained from the average of $1 / C_{i}^{0}$ for all organics weighed by the reaction rate with $\mathrm{OH}$, which in a certain way reflect the overall saturation vapor pressures.

Substituting Eqs. (16), (18) and (19) into Eq. (15), one can get

$\frac{\mathrm{d} m_{\mathrm{t}}}{\mathrm{d} t}=R_{\mathrm{OH}} \cdot m_{\mathrm{t}} \cdot\left(\frac{1}{\bar{C}_{i+}^{0}}-\frac{1}{\bar{C}_{i}^{0}}\right)$.

Then, as Eq. (17), one can also define

$\mathrm{GE}_{\mathrm{OH}}(t)=\frac{1}{\bar{C}_{i+}^{0}}-\frac{1}{\bar{C}_{i}^{0}}$.

$\mathrm{GE}_{\mathrm{OH}}(t)$, a system describing quantity, is derived here in order to characterize the chemical system. It is an overall average of $\mathrm{GE}_{\mathrm{OH}}(t, i)$ weighted by reaction rate with $\mathrm{OH}$ of each species. The molecular weight of $i+$ is assumed to be similar to that of $i$, i.e., neither functionalization nor fragmentation change the molecular dramatically. In the case of fragmentation which could change molecular weight significantly, the relationships above still hold with a slight change of the format (as shown in Appendix A).

Substituting Eq. (21) into Eq. (20),

$\frac{\mathrm{d} m_{\mathrm{t}}}{\mathrm{d} t}=R_{\mathrm{OH}} \cdot m_{\mathrm{t}} \cdot \mathrm{GE}_{\mathrm{OH}}(t)$.

Arranging Eq. (22), one can get

$\mathrm{GE}_{\mathrm{OH}}(t)=\frac{\frac{\mathrm{d} m_{\mathrm{t}}}{\mathrm{d} t}}{R_{\mathrm{OH}} \cdot m_{\mathrm{t}}}$.

Equation (22) shows a quantitative relationship of the particle mass growth rate with the reaction rate of $\mathrm{OH}$ with total organics, which are linked by $\mathrm{GE}_{\mathrm{OH}}(t)$. $\mathrm{GE}_{\mathrm{OH}}(t)$ is the 
mass growth rate normalized to the $\mathrm{OH}$ reaction rate and mass concentration, i.e., the mass growth rate per $\mathrm{OH}$ reacted per aerosol mass concentration (as shown in Eq. 23). It is a metric of how effectively the reaction with $\mathrm{OH}$ changes the mass growth rate at a given mass concentration in a reaction system. $\mathrm{GE}_{\mathrm{OH}}(t)$ has a unit of $\mathrm{cm}^{3}$ molecules ${ }^{-1}$ (reciprocal of the unit of the concentration). It relates to the change in overall saturated concentration of reaction products upon reaction with $\mathrm{OH}$ as shown in Eq. (21). In our case, where we measured $\mathrm{OH}$ and $k_{\mathrm{OH}}, R_{\mathrm{OH}}$ is directly accessible. The reaction rate of $\mathrm{OH}$ with total organics was calculated using the measured $k_{\mathrm{OH}}$ and subtracting the $\mathrm{OH}$ reactivity of inorganic species ( $\left.\mathrm{NO}, \mathrm{NO}_{2}, \mathrm{CO}\right)$. The contribution of $\mathrm{HONO}$ to the total $\mathrm{OH}$ reactivity is neglected $(<1 \%)$ since the HONO concentrations are fairly low in these experiments (maximum peak concentration of 300 pptv as measured by a long-path absorption photometer, LOPAP; Häseler et al., 2009).

Note that in Eq. (1) we assumed that the particle is in equilibrium with the gas phase. When the concentrations of condensing species changes slowly relative to the timescale for the gas-particle equilibrium, gas-particle equilibrium is assumed to be established at any moment (Zhang et al., 2012). This quasi-equilibrium approach was used here and compounds partition between gas and particle phase through dynamic condensation and evaporation (Pankow, 1994; Odum et al., 1996). Theoretically many factors, such as diffusion, surface accommodation, etc., can affect the timescale for gasparticle equilibrium (Shiraiwa and Seinfeld, 2012) and hence affect the particle mass growth. For example, several recent studies suggest that particles may exist in a viscous state (e.g., Vaden et al., 2011; Virtanen et al., 2010; RenbaumWolff et al., 2013) and particle-phase diffusion could play a role in the particle growth kinetics. In addition, the particlephase photolysis is not included in this derivation, which could also potentially affect the gas-particle equilibrium. As a result, the gas-particle equilibrium may not necessarily be reached all the time. These are the limitations of the method used in this study. If the equilibrium is not reached, the mass growth rate in this case is the lower limit for the contribution from gas-phase condensation. The deviation from the equilibrium would result in a higher $\mathrm{GE}_{\mathrm{OH}}(t)$.

\section{Results and discussion}

\subsection{Multi-generation reaction process and particle growth}

Figure 1 shows the time-dependent particle growth curve (particle mass concentration as a function of measured monoterpene consumed) from the $\mathrm{OH}$ oxidation of $\alpha$-pinene, $\beta$-pinene and limonene. After one monoterpene life time (when the monoterpene concentration decreased to $1 / \mathrm{e}$ of the initial concentration), only 13,33 and $25 \%$ of the total mass was reached for the $\mathrm{OH}$ oxidation of $\alpha$-pinene, $\beta$ - pinene and limonene, respectively. This indicates the importance of higher generation products in the SOA formation from $\mathrm{OH}$ oxidation of each monoterpene $(\mathrm{Ng}$ et al., 2006). Our results differ from several previous studies carried out at much higher VOC and SOA concentrations $(\mathrm{Ng}$ et al., 2006, 2007). $\mathrm{Ng}$ et al. (2006) showed that the timedependent growth curve is almost linear for terpenes with one double bond such as $\alpha$-pinene and $\beta$-pinene. The difference can be attributed to the difference of VOC and particle concentration. At high particle mass loading, the species with relatively high volatility such as first generation products significantly condense. At low particle loading, only the species with relatively low volatility which require more oxidation steps (by $\mathrm{OH}$ ) can significantly condense onto the particle phase. Consequently, the later generation products play important roles in the particle formation in this study. The importance of multi-generation products agrees with Eddingsaas et al. (2012), who showed that particle growth continues well after two lifetimes of $\alpha$-pinene with respect to $\mathrm{OH}$ oxidation at low $\mathrm{NO}_{\mathrm{x}}$ condition.

In contrast to $\mathrm{OH}$ oxidation, the total mass concentration increased roughly linearly with the consumed monoterpene concentration for the ozonolysis of each monoterpene (Fig. S1). The time-dependent growth curves of three monopterpenes in the ozonolysis experiments agree with previous studies (Ng et al., 2006; Zhang et al., 2006) and a recent study of Ehn et al. (2014) showing the formation of first generation products as the rate-limiting step. There was an apparent positive offset on the hydrocarbon consumed for $\alpha$ pinene and $\beta$-pinene, and barely an offset for limonene, since the reaction products needed to reach their saturation concentration to condense on the particle phase. For limonene, within the time resolution of our measurement they reached the saturation concentration immediately. The offsets are consistent with the findings of the nucleation threshold of monoterpenes (Bernard et al., 2012; Mentel et al., 2009). The differences of the threshold concentrations of different monoterpenes are related to their properties.

To further investigate the role of multi-generation oxidation by $\mathrm{OH}$, the particle mass concentration and the median size as a function of $\mathrm{OH}$ dose are shown in Fig. 2. For all three monoterpenes, the particle mass concentration increased and size grew as the reaction proceeded and monoterpene reacted with $\mathrm{OH}$ (increasing $\mathrm{OH}$ dose). Then the increase of the mass concentration and growth of size with respect to $\mathrm{OH}$ dose started to slow down gradually and subsequently leveled off. Particle size even decreased after leveling off in the case of limonene. For $\alpha$-pinene, the photooxidation reaction stopped in the dark after the louvre system of the chamber had been closed before the particle mass could level off. The changes in the particle growth in Fig. 2a were probably attributed to the significant fluctuation of $\mathrm{OH}$ concentration resulting from the cloud coverage which also caused significant fluctuations in the reaction rate of total organics with $\mathrm{OH}$ in Fig. 4a. 

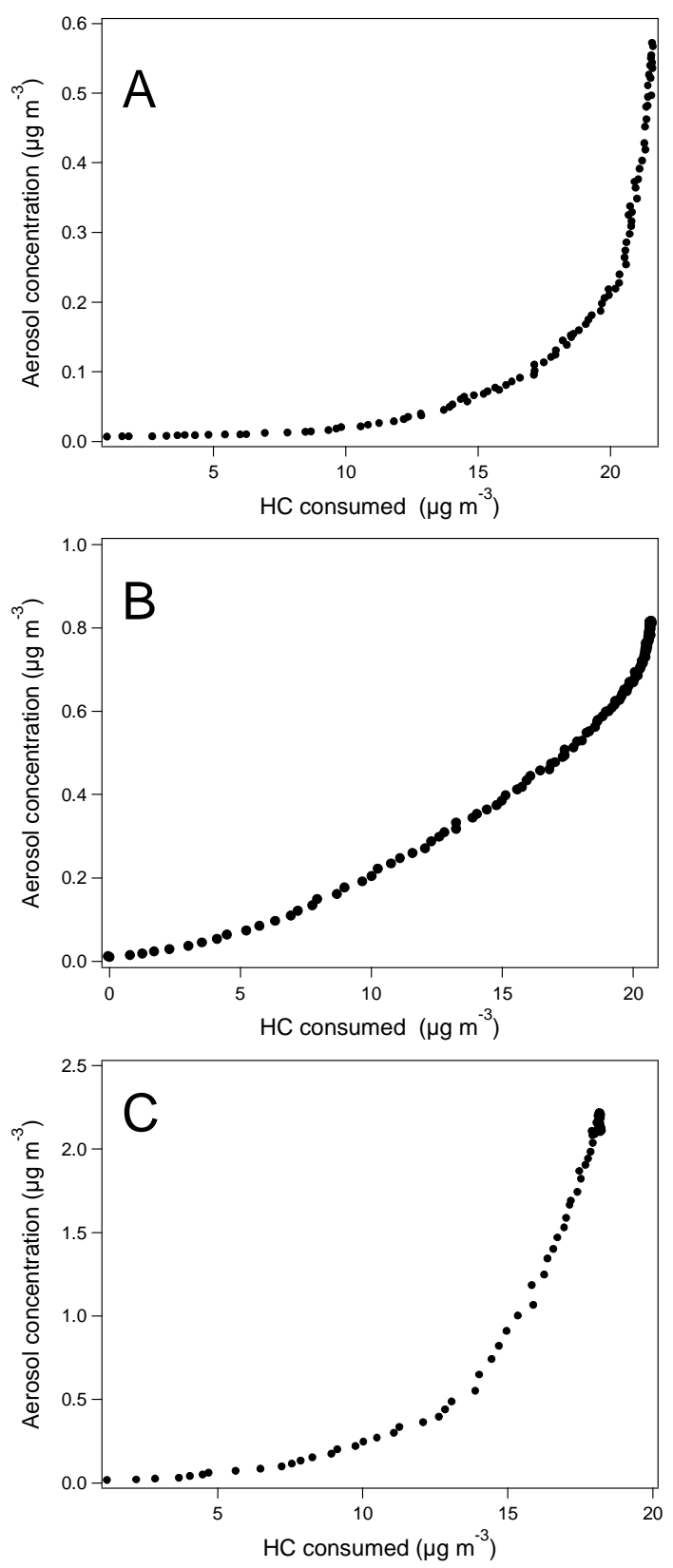

Figure 1. Time-dependent growth curve of aerosols from the $\mathrm{OH}$ oxidation of $\alpha$-pinene (a), $\beta$-pinene (b) and limonene (c) as function of hydrocarbon (HC) consumed (monoterpene here) from measurement.

In the beginning of the reaction, monoterpene reacted with $\mathrm{OH}$ generating low volatility compounds by the functionalization process (Hallquist et al., 2009), which condensed on the particle and resulted in the particle mass increase and size growth. The formation of the low volatility compounds such as 3-methyl-1,2,3-butanetricarboxylic acid (3-MBTCA) has been found from monoterpene oxidation in one of our previous studies (Emanuelsson et al., 2013). This has also been found from the oxidation of monoterpene and its first gen- eration products by a number of studies (Hallquist et al., 2009; Jaoui et al., 2005; Szmigielski et al., 2007; Claeys et al., 2007; Müller et al., 2012; Kristensen et al., 2014). These condensing compounds still continued reacting with $\mathrm{OH}$ which could lead to functionalization as well as fragmentation (Hallquist et al., 2009; Kroll et al., 2009). Fragmentation can generate high-volatility species thus promoting evaporation. Since fragmentation increased with $\mathrm{O} / \mathrm{C}$ and the role of functionalization decreased (Kroll et al., 2009; ChaconMadrid and Donahue, 2011; Chacon-Madrid et al., 2010), the role of fragmentation became more and more significant as the reaction proceeded. When the fragmentation dominated over functionalization, the overall volatility of the products increased, i.e., the saturated vapor pressures increased. When the overall concentration of condensing species dropped below the overall saturation concentration due to the reaction and dilution, a net negative flux of condensable compounds occurred and these compounds started to evaporate from the particles. Therefore, the particle size first reached a plateau and even diminished as observed in the limonene oxidation experiment. For $\alpha$-pinene, particle growth did not reach the plateau phase. This is because the reaction was stopped by closing the louvre when particles were still growing.

Moreover, time series of $\mathrm{GE}_{\mathrm{OH}}(t)$, the metric of particle growth efficiency due to reaction with $\mathrm{OH}$, shed light on the role of functionalization and fragmentation in the reaction process. Figure 3 shows that the $\mathrm{GE}_{\mathrm{OH}}(t)$ time series and the particle mass concentration as well as total $\mathrm{OH}$ reactivity of organics for comparison. The change in $\mathrm{GE}_{\mathrm{OH}}(t)$ reflects the evolution of the overall volatility of organics undergoing reaction with $\mathrm{OH}$ and the relative role of functionalization and fragmentation. $\mathrm{GE}_{\mathrm{OH}}(t)$ was positive and increased fast in the beginning of the reaction. This indicates that the reaction products had a lower volatility than the reactants, i.e., lower saturation concentration (refer to Eq. (21)). As the volatility decreased, $\mathrm{GE}_{\mathrm{OH}}(t)$ increased. The decreased volatility was caused by functionalization, which played a dominant role in the beginning. Afterwards, $\mathrm{GE}_{\mathrm{OH}}(t)$ gradually decreased, which indicates the decrease of overall volatility of the organics slowed down. This indicates an increasing role of fragmentation since fragmentation cleaved the carbon frame and formed some smaller molecules with higher volatility. As the reaction proceeded, the products got more oxidized and the $\mathrm{O} / \mathrm{C}$ ratio of products increased; the fragmentation of the compounds became more and more significant (Kroll et al., 2009; Chacon-Madrid and Donahue, 2011; ChaconMadrid et al., 2010). After the continuous decrease, $\mathrm{GE}_{\mathrm{OH}}(t)$ decreased to almost zero or even negative for the limonene case (Fig. 3c). This indicates that overall volatility of organics almost stopped decreasing and even increased after further reactions of the functionalized intermediates with $\mathrm{OH}$ (see limonene case in Fig. 3c). When the overall volatility of the reactants is equal to that of the products, $\mathrm{GE}_{\mathrm{OH}}(t)$ is equal to zero. From Fig. 3 one can recognize that $\mathrm{GE}_{\mathrm{OH}}(t)$ had decreased dramatically in the relatively early period of the reac- 

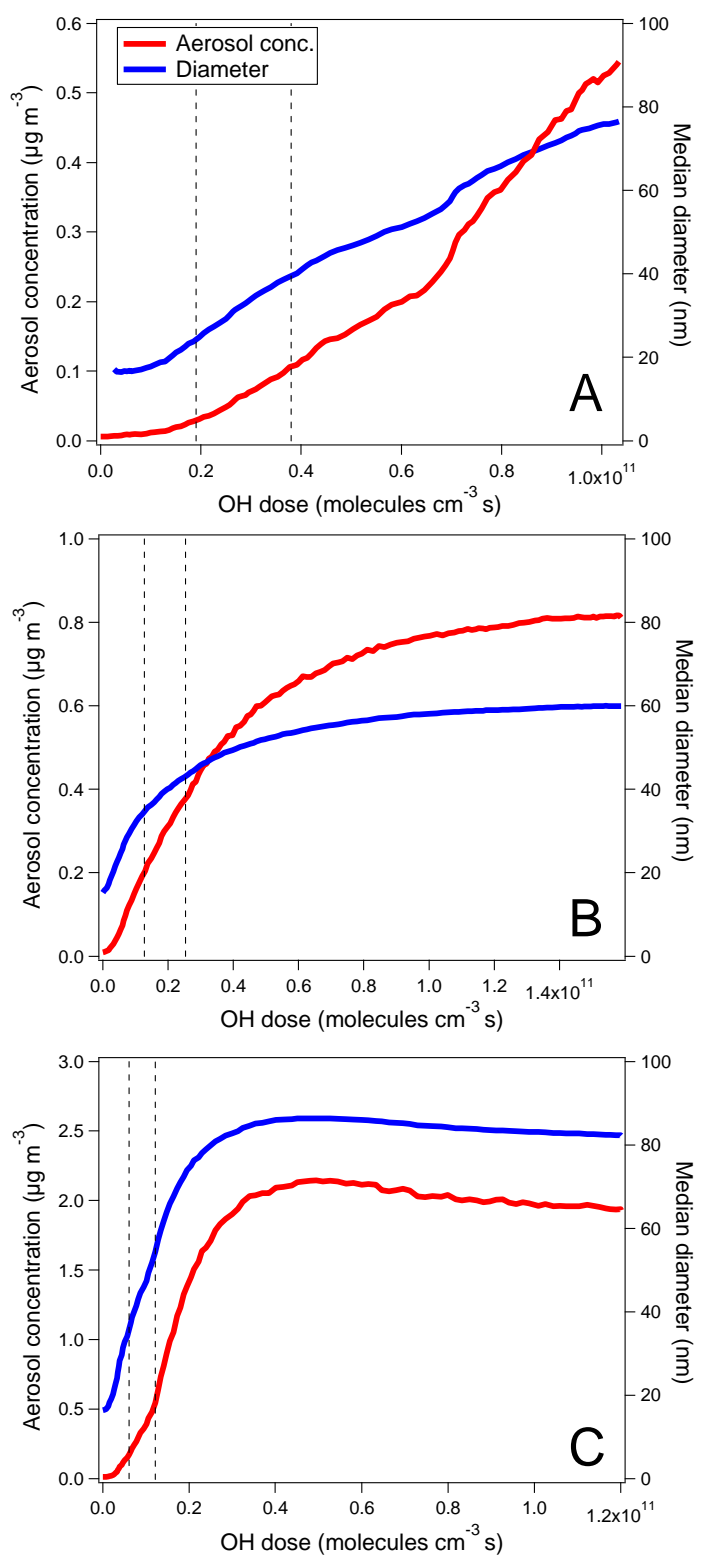

Figure 2. Particle mass concentration and median diameter as a function of $\mathrm{OH}$ dose for the $\mathrm{OH}$ oxidation of $\alpha$-pinene (a), $\beta$-pinene (b) and limonene (c). The dashed vertical lines correspond to the one and two lifetimes of each monoterpene with respect to $\mathrm{OH}$ oxidation. The lifetime is the time when the monoterpene concentration decreases to $1 / \mathrm{e}$ of the initial concentration.

tion (within approximate two lifetimes) when the mass concentration was still low, indicating the fragmentation started to play an important role. The vibrations in the $\mathrm{GE}_{\mathrm{OH}}(t)$ of $\alpha$ pinene are attributed to the fast change of $\mathrm{OH}$ concentration due to the cloud coverage and then clearing up, as mentioned above.

For comparison, the $\mathrm{H} / \mathrm{C}$ and $\mathrm{O} / \mathrm{C}$ time series of SOA are also shown in Fig. 3. The change in the $\mathrm{H} / \mathrm{C}$ and $\mathrm{O} / \mathrm{C}$ ratios supports our analysis of the role of functionalization
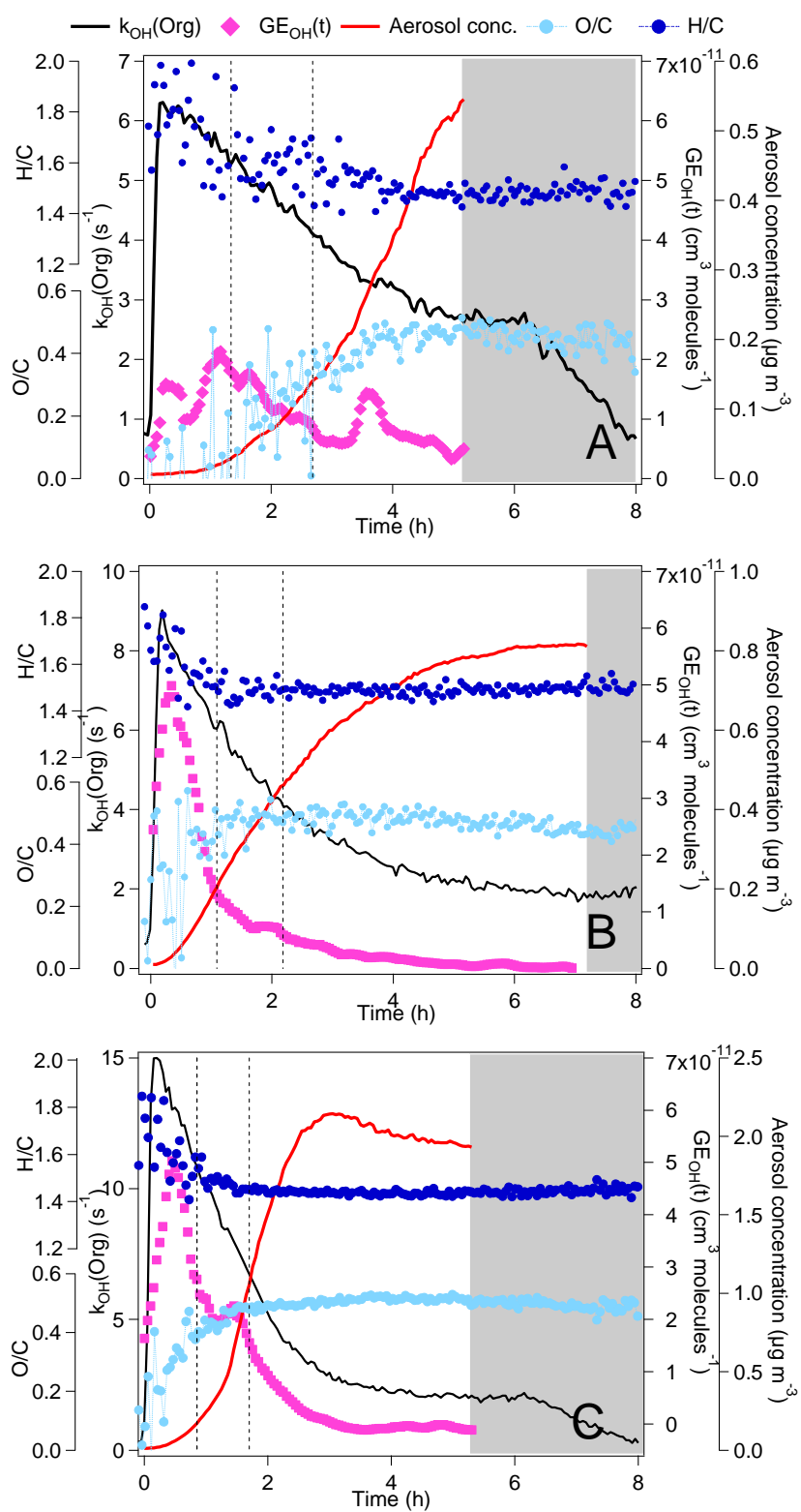

Figure 3. Time series of $\mathrm{GE}_{\mathrm{OH}}(t)$ (particle mass growth efficiency with respect to the reaction of $\mathrm{OH}$ with organics, refer to the text for details; for clarity, a 7 points moving average is shown), $k_{\mathrm{OH}}(\mathrm{Org})$ (OH reactivity of total organics), $\mathrm{O} / \mathrm{C}$ and $\mathrm{H} / \mathrm{C}$ from AMS data, and aerosol mass concentration in the $\mathrm{OH}$ oxidation of $\alpha$-pinene (a), $\beta$-pinene (b) and limonene (c). The shaded area shows the dark period. The dashed vertical lines in each panel show the one and two lifetimes of monoterpene.

and fragmentation. $\mathrm{GE}_{\mathrm{OH}}(t)$ had decreased dramatically to a much lower value when the $\mathrm{O} / \mathrm{C}$ ratio increased to around 0.4 and leveled off. Accordingly, $\mathrm{H} / \mathrm{C}$ started to decrease from the beginning of the reaction and then leveled off at the same time as $\mathrm{O} / \mathrm{C}$. The decrease of $\mathrm{GE}_{\mathrm{OH}}(t)$ reflects the increasing role of fragmentation. As a reference, Kroll et al. (2009) showed that for the reaction of squalane with 
$\mathrm{OH}$ fragmentation dominates when the organics are moderately oxidized $(\mathrm{O} / \mathrm{C} \approx 0.4)$, although the reaction compounds are different. The branching ratio of fragmentation and functionalization has been parameterized as the power law of O / C (Donahue et al., 2012; Jimenez et al., 2009). The higher $\mathrm{O} / \mathrm{C}$, the higher the role of fragmentation plays. Based on the $\mathrm{GE}_{\mathrm{OH}}(t)$ time series, the particle formation efficiency in respect to the reaction with $\mathrm{OH}$ was high in the beginning of the reaction although the mass growth rate was low. In contrast, at the later period of the reaction, $\mathrm{GE}_{\mathrm{OH}}(t)$ was low and the mass growth was mainly attributed to the role of favorable partitioning at higher organic mass loading.

The occurrence of fragmentation in the reaction is supported by the formation of acetone, one small volatile compound of monoterpene oxidation products. An increased acetone concentration was observed in the $\mathrm{OH}$ oxidation of all monoterpenes as reaction proceeded (as shown in Fig. S4 for $\alpha$-pinene as an example), implying the role of fragmentation in producing small volatile compounds. The acetone concentration was corrected for the dilution loss. However, we did not observe a significantly faster acetone formation rate in the later period of the reaction compared to the early period of the reaction because acetone formation depends on its precursor concentrations and $\mathrm{OH}$ concentration, which were not monotonic in our study. Unfortunately, many of the products in the $\alpha$-pinene oxidation cannot be detected and/or quantified by PTR-MS or GC-MS due to the loss to the sampling line or degradation in the instrument, which prevents us from doing further in-depth analysis.

In addition, $\mathrm{GE}_{\mathrm{OH}}(t)$ can shed some light on the vapor pressure of the reaction products. Since the volatility of products decreases around 1-2 orders of magnitude in functionalization (Ziemann and Atkinson, 2012), in the beginning of the reaction when functionalization dominated, $C_{n, i+}^{0} \ll$ $C_{n, i}^{0}$. Then, based on Eq. (21), the following equation is tenable:

$\mathrm{GE}_{\mathrm{OH}}(t)=\frac{1}{\bar{C}_{n, i+}^{0}}$.

Since $\bar{C}_{i+}^{0}$ is an average saturation pressure weighed in a certain way as shown in Eq. (18). Equation (24) provides a rough estimate of the overall vapor pressure of the organics from experimentally obtained $\mathrm{GE}_{\mathrm{OH}}(t)$. For $\alpha$-pinene, $\beta$ pinene and limonene $\mathrm{OH}$ oxidation, the overall vapor pressure varied from around $2 \times 10^{-4}$ to $1 \times 10^{-3} \mathrm{~Pa}, 6 \times 10^{-5}$ to $1 \times 10^{-3} \mathrm{~Pa}$ and $8 \times 10^{-5}$ to $2 \times 10^{-3}$, respectively. As a reference, the lower values for each monoterpene system are of the same order of magnitude as the estimated vapor pressure of the middle values between pinonic acid and pinic acid, and norpinonic acid and keto-limonic acid, based on the structure-activity relationship (Compernolle et al., 2011).

We established the relationship of particle mass growth rate with the reaction rate of $\mathrm{OH}$ with organics. The relationship of the particle size growth rate with the reaction rate is not straightforward. The size growth rate is proportional to the deviation of the concentrations of condensing species from their equilibrium concentrations, while the reaction rate of monoterpene with $\mathrm{OH}$ and $\mathrm{O}_{3}$ is proportional to the rate of the increase of condensing species concentrations, i.e., the derivative of the concentrations. Additionally, the equilibrium concentrations of the each species changes continuously with their varying molar fractions in the particle phase during the reaction. Therefore, the reaction rate is only indirectly related to the size growth rate and should not necessarily correlate with the size growth rate as observed in Fig. 4a and c. Still some variations in the size growth rate and mass growth rate follow the variations of the reaction rate of $\mathrm{OH}$ with organics and/or reaction rate of $\mathrm{OH}$ with monoterpenes (such as Fig. 4a, b and c). These variations in the reaction rates as well as the growth rates were mostly caused by sudden changes of the $\mathrm{OH}$ concentration due to variations of solar radiation affected by cloud coverage. In addition, the fluctuations in the growth rate were partly attributed to the fluctuations in the particle mass or size and to deriving the growth rate from fitting the particle mass or particle size as a function of time.

Comparing the particle growth of $\mathrm{OH}$ oxidation and ozonolysis, the ratios of the peak $\mathrm{OH}$ reaction rate to the $\mathrm{O}_{3}$ reaction rate for $\alpha$-pinene, $\beta$-pinene and limonene were around 1.0, 1.2 and 0.5 , respectively. The corresponding ratios of peak size growth rates for $\mathrm{OH}$ oxidation to that for ozonolysis were around 1.0, 1.5 and 1.1. At a similar monoterpene concentration and similar reaction rate of $\mathrm{OH}$ or $\mathrm{O}_{3}$ with monoterpene, the size growth rates were comparable. This comparison indicates that generally $\mathrm{OH}$ oxidation and ozonolysis have similar efficiency in the particle growth of $\alpha$-pinene, $\beta$-pinene and limonene. This result is in contrast with the study of Hao et al. (2009), who found a much more efficient role of ozonolysis in particle growth from plant emissions than that of $\mathrm{OH}$ oxidation. Yet, our study agrees with Burkholder et al. (2007), who reported the nearly indistinguishable particle size growth rate for different oxidation sources. Nevertheless, our experiments differ from both of these studies in terms of $\mathrm{OH}$ scavenger used (CO used in this study; cyclohexane and butanol used in Burkholder et al. (2007) and Hao et al. (2009), respectively). Since CO can cause a higher $\mathrm{HO}_{2} / \mathrm{RO}_{2}$ ratio than cyclohexane and butanol, different $\mathrm{OH}$ scavengers could result in different radical chemistry which could further alter the reaction pathways and products, and finally could affect particle growth.

\subsection{New particle formation and SOA yield}

Figure 5 shows the particle number concentration, mass concentration, surface concentration and median diameter of aerosols from each monoterpene by $\mathrm{OH}$ oxidation and ozonolysis. The particle number concentrations of $\mathrm{OH}$ oxidation experiments were around $2 \times 10^{3}-6 \times 10^{3} \mathrm{~cm}^{-3}$. The particle number concentrations from the ozonolysis of 

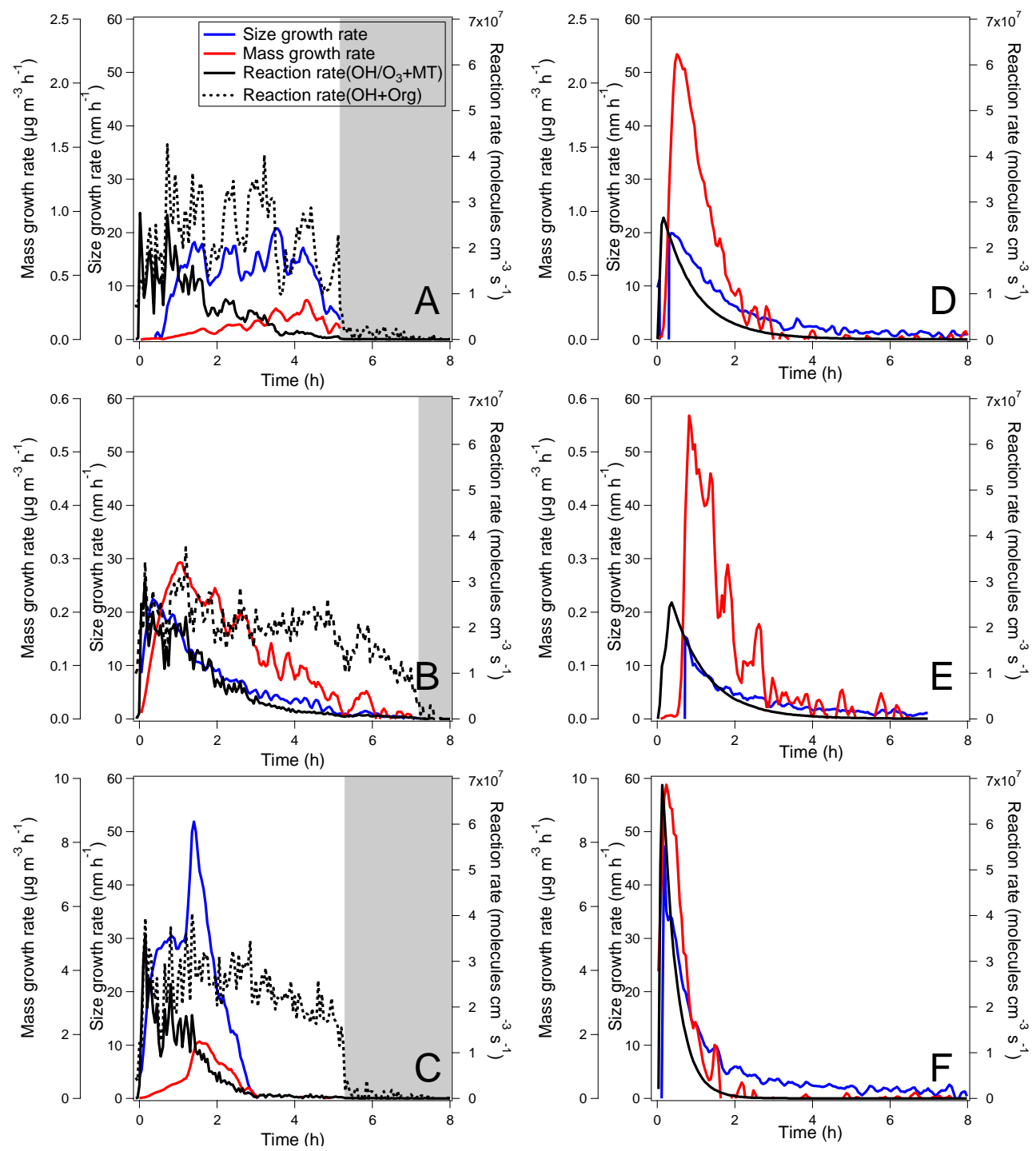

Figure 4. Particle size growth rate, mass growth rate and reaction rate of $\mathrm{OH}$ or $\mathrm{O}_{3}$ with $\alpha$-pinene (a, d), $\beta$-pinene (b, e) and limonene (c, f). The left panels are from $\mathrm{OH}$ oxidation (the shaded area shows the dark period) and right panels from ozonolysis in the presence of $\mathrm{CO}$ as $\mathrm{OH}$ scavenger. For the $\mathrm{OH}$ oxidation, the overall reaction rate of $\mathrm{OH}$ with total organics (reaction $\mathrm{rate}(\mathrm{OH}+\mathrm{Org}))$ is also shown.

monoterpene were around $0.4 \times 10^{5}-1.6 \times 10^{5} \mathrm{~cm}^{-3}$, which were much higher than that generated by $\mathrm{OH}$ oxidation of the respective monoterpene. However, we have no indications what compounds eventually initiated the NPF from ozonolysis in the SAPHIR chamber made of Teflon FEP. The role of $\mathrm{OH}$ oxidation and ozonolysis in the SOA nucleation and growth from monoterpenes have been reported by a number of studies before with inclusive results (Bonn and Moortgat, 2002; Burkholder et al., 2007; Hao et al., 2009; Mentel et al., 2009); however, experiments were performed often at higher VOC and aerosol concentrations. In addition, the role of monoterpene ozonolysis in nucleation in the presence of $\mathrm{SO}_{2}$ (without $\mathrm{OH}$ scavenger) was shown by Ortega et al. (2012).
In our JPAC glass chamber (Mentel et al., 2009), OH and $\mathrm{H}_{2} \mathrm{SO}_{4}$ are needed to initiate NPF (Mentel et al., 2009; Kiendler-Scharr et al., 2009a, 2012; Ehn et al., 2014); it is possible that in Teflon chambers in absence of $\mathrm{OH}$ and significant $\mathrm{H}_{2} \mathrm{SO}_{4}$ formation, other unknown compounds (perfluorinated acids) may play a role.

SOA yields observed in this study are similar to those observed before. SOA yield of $\alpha$-pinene, $\beta$-pinene and limonene by $\mathrm{OH}$ oxidation was $2.5,6.8$ and $16.9 \%$ at the aerosol loading of $0.5,0.8$ and $2.1 \mu \mathrm{g} \mathrm{m}^{-3}$, respectively (Fig. S2). Since the multi-generation oxidation was the ratelimiting step, the dynamic yield from $\mathrm{OH}$ oxidation was not used (Presto and Donahue, 2006; Ng et al., 2006) and only the final yield was derived. The aerosol yield of $\alpha$-pinene $\mathrm{OH}$ oxidation is roughly consistent with a previous study (Henry 

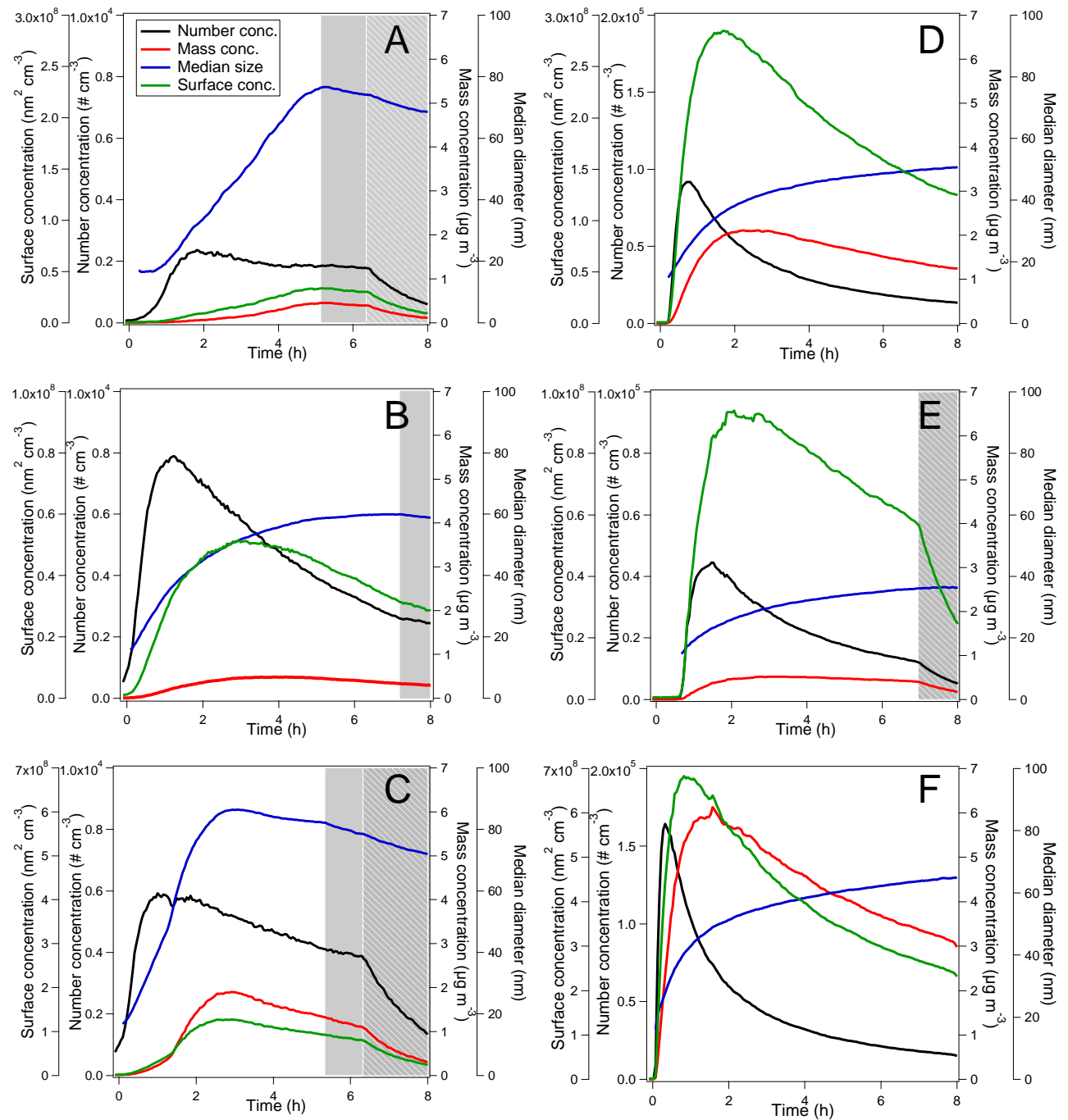

Figure 5. Particle number concentration, mass concentration (not corrected for losses), surface concentration and median diameter of the aerosols from $\alpha$-pinene (a, d), $\beta$-pinene (b, e) and limonene (c, f). The left panels are from $\mathrm{OH}$ oxidation (the gray shaded area shows the dark period) and right panels from ozonolysis. The gray hatched area corresponds to the flushing out period.

et al., 2012), although there were only few data points in that study overlapping the range of our study $\left(<1 \mu \mathrm{g} \mathrm{m}^{-3}\right.$, exact data not available from Henry et al., 2012), and thus not shown in the figure). For $\beta$-pinene and limonene, there are few data of the aerosol yield of $\mathrm{OH}$ oxidation available especially at a low aerosol loading similar to this study in the literature (Griffin et al., 1999; Hoffmann et al., 1997; Kim et al., 2012).

The particle yields for the ozonolysis experiments for $\alpha$ pinene, $\beta$-pinene and limonene (shown in Fig. S2, together with selected literature data at similar mass loadings) are approximately in the range of or slightly higher than literature values (Pathak et al., 2007, 2008; Shilling et al., 2009; Saathoff et al., 2009; Zhang et al., 2006). The difference can be attributed to the difference in experimental conditions such as $\mathrm{OH}$ scavenger type, the temperature, $\mathrm{RH}$, etc. The aerosol yields of ozonolysis for $\alpha$-pinene and limonene were higher than that of $\mathrm{OH}$ oxidation, while similar between both oxidation cases for $\beta$-pinene. The difference in the aerosol yield could be due to the difference in reaction pathways and products composition between the $\mathrm{OH}$ oxidation and ozonolysis. Also the temperature of the ozonolysis was lower than the $\mathrm{OH}$ oxidation, which may affect the SOA yield. However, Pathak et al. (2007) only observed weak dependence of SOA yield from $\alpha$-pinene ozonolysis on temperature from 288 to $303 \mathrm{~K}$, and especially at low $\alpha$-pinene there was little temperature dependence. Therefore, temperature is likely to have only a minor effect on the SOA yield of ozonolysis here. 


\subsection{Chemical composition}

The $\mathrm{H}$ / C ratio vs. the O / C ratio plot, known as Van Krevelen diagram, for the aerosols from $\mathrm{OH}$ oxidation and ozonolysis is shown in Fig. 6. The $\mathrm{O} / \mathrm{C}$ ranges for both oxidation cases were similar, around $0.3-0.6$. The $\mathrm{O} / \mathrm{C}$ ranges are consistent with the $\mathrm{O} / \mathrm{C}$ range from $\alpha$-pinene photooxidation and ozonolysis (Chhabra et al., 2011; $\mathrm{Ng}$ et al., 2011; Pfaffenberger et al., 2013). They also agree with the $\mathrm{O} / \mathrm{C}$ value $(0.33-0.68)$ in a plant chamber observations for monoterpene-dominated emission mixtures (Kiendler-Scharr et al., 2009b) when one calculates $\mathrm{O} / \mathrm{C}$ from $f 44$ (the ratio of signal at $m / z 44\left(\mathrm{CO}_{2}^{+}\right)$to total organics) (Ng et al., 2010).

The $\mathrm{H} / \mathrm{C}$ ratio of SOA from $\mathrm{OH}$ oxidation was around 1.4-1.6, slightly lower than that of the precursor monoterpene $(\mathrm{H} / \mathrm{C}=1.6)$. This indicates that during the reaction oxygen was added to the monoterpene without significant loss of hydrogen especially in the initial period of the reaction. SOA from $\mathrm{OH}$ oxidation of all three monoterpenes tended to follow a slope of shallower than -1 starting from monoterpene in the Van Krevelen diagram (Fig. 6a-c). This is in contrast with the findings by Heald et al. (2010), but consistent with those of Chhabra et al. (2011) and $\mathrm{Ng}$ et al. (2011). Heald et al. (2010) found atmospheric OA follows a slope of -1 in the Van Krevelen diagram based on a variety of ambient and laboratory studies, which indicates the addition of the carboxylic group or equal addition of the carbonyl and hydroxyl groups to average saturated hydrocarbon. However, in this study, monoterpenes are unsaturated hydrocarbons. Therefore, oxidation such as adding two carbonyl or carboxylic acid groups per double bond can happen without significant loss of hydrogen, resulting in a slope shallower than -1 . This finding agrees with that of Chhabra et al. (2011) who investigated a series of unsaturated hydrocarbons. Oxidation without significant loss of hydrogen can also be achieved by a non-classical path, inserting $\mathrm{O}$ (O-O) into C-H (C-C) bonds (Ehn et al., 2012, 2014). In the classical path, increasing carbonylization/carboxylization in saturated parts of the condensable molecules leads to increase of $\mathrm{O} / \mathrm{C}$ at simultaneous decrease of $\mathrm{H} / \mathrm{C}$. After the initial period of particle formation (around one lifetime of monoterpene), elemental composition of SOA from OH oxidation seemed to follow a slope more close to -1 . This indicates that the condensable species forming SOA underwent more efficient hydrogen loss upon oxidation. Since the double bond is more reactive and reacted first, the carbon chain in the initial products became more saturated. Further classical oxidation of these products required hydrogen loss as ambient OAs (Heald et al., 2010). For the SOA from $\mathrm{OH}$ oxidation, $\mathrm{H} / \mathrm{C}$ decreased and $\mathrm{O} / \mathrm{C}$ increased generally during the reaction. In the later period of the reaction the change in $\mathrm{O} / \mathrm{C}$ and $\mathrm{H} / \mathrm{C}$ was quite minor (Fig. 3). The relative stability of the $\mathrm{O} / \mathrm{C}$ and $\mathrm{H} / \mathrm{C}$ is likely to be attributed to that, in the early period of the reaction (before $\mathrm{O} / \mathrm{C}$ reaches the maximum value), low concentrations of multi-generation products were generated via functionalization and had already condensed on the particle phase. As the reaction proceeded, more of these similar multi-generation products were formed and continued to condense on the particle. Further oxidation of the multi-generation products may cause the fragmentation resulting in the formation of highvolatility oxidation products, which did not condense significantly on the particle. As a result, the $\mathrm{O} / \mathrm{C}$ ratio did not manifest significant increase in the particle phase. This is consistent with the analysis of functionalization and fragmentation via the evolution of $\mathrm{GE}_{\mathrm{OH}}(t)$. For $\beta$-pinene and limonene, $\mathrm{O} / \mathrm{C}$ even decreased slightly at the later period of the reaction (Fig. 6b). This could be due to oligomerization after condensation forming larger units while releasing water (formation of esters) or $\mathrm{O}_{2}$ (dimerization of hydroperoxides) or be due to fragmentation of the products leading to more volatile products.

For SOA from ozonolysis, the $\mathrm{H} / \mathrm{C}$ was around 1.2-1.4, which was distinctively lower than that of the $\mathrm{OH}$ oxidation. The lower H / C in the ozonolysis compared to photooxidation was reported by Chhabra et al. (2011). It seemed that a process with significant hydrogen loss such as addition of carbonyl plays a more important role in the SOA formation from ozonolysis compared to $\mathrm{OH}$ oxidation. In the reaction of monoterpene with $\mathrm{O}_{3}$, taking $\alpha$-pinene as an example, the $-\mathrm{CH}_{2}-$ group can be converted to the $-\mathrm{C}=\mathrm{O}$ group which reduces the $\mathrm{H} / \mathrm{C}$ and increase $\mathrm{O} / \mathrm{C}$. One path way is shown in Fig. S7. Monoterpene reacts with $\mathrm{O}_{3}$ producing $\mathrm{RO}_{2}$. radical, which can undergo an internal hydrogen shift forming another $\mathrm{R}_{1} \mathrm{O}_{2}$. radical (Ehn et al., 2014). The $\mathrm{R}_{1} \mathrm{O}_{2}$. radical can react with other $\mathrm{RO}_{2}$. radical forming the $-\mathrm{C}=\mathrm{O}$ group at the same time losing two hydrogen atoms.

In the individual ozonolysis experiments, the $\mathrm{O} / \mathrm{C}$ and $\mathrm{H} / \mathrm{C}$ reached a stable value shortly $(<1 \mathrm{~h})$ after the reaction started and then did not show significant change. The different trend with time between the $\mathrm{OH}$ oxidation and ozonolysis was caused by the different reaction process. In the $\mathrm{OH}$ oxidation, after the particle formed, the reaction products were subject to further reaction with $\mathrm{OH}$. Hence the reaction products $\mathrm{H} / \mathrm{C}$ and $\mathrm{O} / \mathrm{C}$ kept evolving. In contrast, in the ozonolysis the reaction ceased once $\mathrm{O}_{3}$ reacted with monoterpene. Therefore, there was no further significant change in the $\mathrm{O} / \mathrm{C}$ and $\mathrm{H} / \mathrm{C}$ in the ozonolysis.

\subsection{Uncertainty of particle mass concentration}

The particle mass concentration is used to derive the particle growth efficiency in this study. Uncertainty of the particle mass concentration relates to uncertainties in particle wall loss, dilution and vapor wall loss. The particle mass concentration has been corrected for the dilution and particle wall loss. The corrected particle mass concentration may be affected by the uncertainty of different particle correction methods. In this study, we determined the particle wall-loss rate using an exponential fit of the decay of the particle num- 

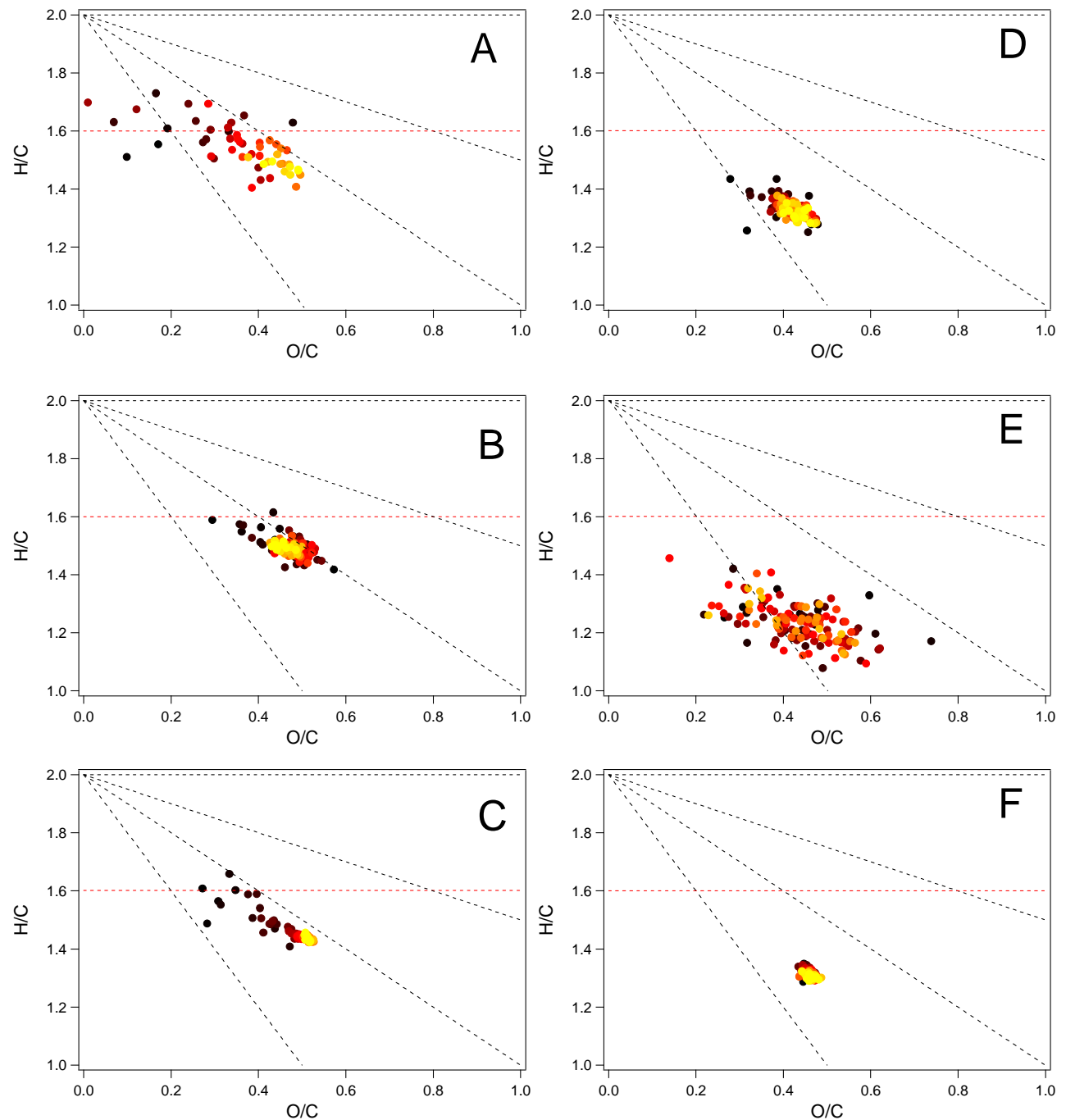

Figure 6. H / C and O / C ratios of SOA from the OH oxidation and ozonolysis of $\alpha$-pinene (a, d), $\beta$-pinene (b, e) and limonene (c, f). The left panels are from $\mathrm{OH}$ oxidation and right panels from ozonolysis. Dark color denotes the beginning of the experiments and yellow denotes the later period. The red dashed line correspond to $\mathrm{H} / \mathrm{C}=1.6$. The black dashed lines correspond to the slope of $-2,-1$ and -0.5 .

ber concentration after the nucleation has stopped for several hours (Carter et al., 2005; Fry et al., 2011; Pierce et al., 2008). Another method that has been used to determine the particle wall-loss rate is by fitting the decay particle mass concentration after the condensation has finished (Presto and Donahue, 2006; Pathak et al., 2007). In this study, we found in most of our experiments, the particle wall-loss rate determined through the decay particle mass concentration kept evolving until the end during the photooxidation experiment; this decay rate was lower than that of the period right after the roof was closed and photooxidation stopped. This indicates that particle formation (condensation) was still active and not finished in the light period. In contrast, the particle wall-loss rate through decay of particle number concentration was constant during the later period of the photooxidation reaction and higher than that determined through the decay of particle mass concentration, which supports the condensation did not finish. Therefore, the second method, which used the mass concentration, did not apply to our study and we used the first method, determining the wall-loss rate by particle number concentration. Once the wall-loss coefficient was determined, the particle mass concentration was corrected in every step of the SMPS scans by the dilution and wall-loss rate. Pierce et al. (2008) compared the results from different wallloss correction methods including these two methods mentioned here and a model approach, showing that different methods agree within $10 \%$ for the faster limonene ozonolysis experiment and a factor of two for the slow toluene oxidation experiment. Unfortunately, we cannot compare the difference of these two methods, since the method using the particle mass concentration is not suitable for this study. We estimated the uncertainty by investigating the variability of 
the particle wall-loss rate among different experiments. The relative standard deviation of the particle wall-loss rate is $11 \%$. We did a sensitivity analysis to check the effect of uncertainty of particle wall-loss rate on the corrected mass as shown in Fig. S5. We found the corrected aerosol mass concentration is not sensitive to the uncertainty of the particle wall-loss rate. For $\alpha$-pinene experiment, a change of 10 and $50 \%$ only results in a change of approximately 2 and $9 \%$ of the final corrected particle mass concentration. Considering the uncertainty of our SMPS system $( \pm 10 \%)$, we estimate uncertainty of the corrected particle mass concentration is $12 \%$.

The wall loss of vapor and dilution can also affect the particle concentration which can result in an underestimation of the particle concentration. But in the presence of pre-existing particles, condensation on them will be able to compete with wall loss, depending on the $S / V$ (surface-to-volume ratio) of the chamber, which is very favorable in our large chamber, and surface density of the particles. The wall loss of vapor was investigated in our SAPHIR chamber using experiments in which pinonaldehyde, one important first generation product from $\alpha$-pinene oxidation, was injected into the chamber. The concentration was monitored over several hours. Constant first-order decay with a rate constant of 2.8 $\times 10^{-6} \mathrm{~s}^{-1}$ was observed over a period of $14 \mathrm{~h}$ and no equilibrium was observed. It was not possible to detect rapid initial losses of pinonaldehyde in the SAPHIR chamber due to the chamber setup and injection procedures. The vapor wallloss rate is on the same order of magnitude as described by Loza et al. (2014) but lower than that given by Matsunaga and Ziemann (2010) and Zhang et al. (2014). Different vapor wall-loss rates in different chambers are expected, since vapor wall-loss rates depend on the mixing in the respective chamber, the thickness of the diffusive boundary layer and penetration into the chamber wall (Zhang et al., 2014). Matsunaga and Ziemann (2010) found that vapor wall loss depends on structure and compound vapor pressure in contrast with Zhang et al. (2014) who used one vapor wall-loss rate for all compounds in the whole reaction system. It will result in uncertainties to extrapolate wall-loss rates of pinonaldehyde to all products from monoterpene oxidation. However, as a first approach, we estimate the effect on the particle mass concentration, assuming the wall-loss rate of pinonaldehyde and same particle yields for all lost vapors (the same as in the reaction system). The particle mass concentration would then be underestimated by approximately $17 \%$. Combining the particle wall loss and vapor loss by wall loss and dilution, the uncertainty of the particle mass concentration is estimated to be approximately $30 \%$. Without correcting the vapor wall loss, the particle mass concentration is underestimated, and so is the particle growth efficiency. In addition, the dilution may also affect particle mass concentration through altering the gas-particle equilibrium. Due to the unknown identities, vapor pressure of the compounds and unknown amounts on the particle, it is not possible in this study to correct this effect. However, the compounds contributing to the particle growth here have very low vapor pressure, which may make the effect of dilution on the gas-particle equilibrium less significant.

\section{Conclusions}

In this study, the SOA formation from $\mathrm{OH}$ oxidation of several monoterpenes ( $\alpha$-pinene, $\beta$-pinene and limonene) was investigated at ambient relevant conditions (low OA concentration, low VOC and $\mathrm{NO}_{\mathrm{x}}$ concentrations) and was compared with the SOA formation from ozonolysis ( $\mathrm{CO}$ as the $\mathrm{OH}$ scavenger). The $\mathrm{OH}$ dominant oxidation was achieved at low $\mathrm{O}_{3}$ concentration. Multi-generation reaction process, particle growth, NPF particle yield and chemical composition were analyzed.

The aerosol growth curve reflected the importance of multi-generation products in the $\mathrm{OH}$ oxidation of three monoterpenes. In the $\mathrm{OH}$ oxidation, we found the transition of functionalization and fragmentation correlated with the evolution of particle size and particle mass as a function of $\mathrm{OH}$ dose. A novel method was developed which quantitatively linked the particle mass growth rate to the reaction rate of $\mathrm{OH}$ with organics via a metric of particle growth efficiency of $\mathrm{OH}$ reaction. This method was also used to examine the role of functionalization and fragmentation during the particle formation of monoterpenes by $\mathrm{OH}$ oxidation. Functionalization was found dominant in the beginning of the reaction (within approximately two lifetimes of the monoterpene) and fragmentation started to play an important role after that. The particle growth efficiency of the $\mathrm{OH}$ reaction was high in the beginning of the experiment, although the mass growth rate was low due to the low particle mass. This new method also provided an estimation of overall vapor pressure of the products when functionalization was dominant. We show that the overall vapor pressures vary from $10^{-5}$ to $10^{-3} \mathrm{~Pa}$ in the $\mathrm{OH}$ oxidation. The method of quantitatively linking particle mass growth rate to the $\mathrm{OH}$ reaction rate with organics will be used in other VOC systems and ambient measurements to further investigate the influence of $\mathrm{OH}$ oxidation on the particle growth. The relationship of overall reaction rates of the total organics with $\mathrm{OH}$ with the particle growth rates applies well in well-characterized chamber systems. Such a relationship is being planned to be tested using more VOC systems in the chamber. For the atmosphere, it is much more complex to apply such a method. Different VOC types (such as sesquiterpene, isoprene or linear alkenes) contribute to overall reaction rate of total organics with $\mathrm{OH}$ but may have different particle growth efficiencies resulting in different particle growth rates. This still needs to be characterized in experiments.

The particle size growth rate did not necessarily correlate directly with the reaction rate of monoterpenes with $\mathrm{OH}$ and $\mathrm{O}_{3}$ in individual experiments. Particle size growth rates in- 
duced by the reaction with $\mathrm{OH}$ and ozonolysis were comparable in this study at similar reaction rates of the monoterpenes with $\mathrm{OH}$ and $\mathrm{O}_{3}$. This indicates that $\mathrm{OH}$ oxidation and ozonolysis have comparable efficiency in particle growth. The SOA yields of $\mathrm{OH}$ oxidation and ozonolysis in this study are generally consistent with the values in the literature. Ozonolysis of $\alpha$-pinene and limonene produced a higher aerosol yield than the respective $\mathrm{OH}$ oxidation.

SOA from monoterpene $\mathrm{OH}$ oxidation generally followed a slope of shallower than -1 in the Van Krevelen diagrams, indicative of a process without significant loss of hydrogen during the oxidation. In the later period of the reaction (after around one lifetime of monoterpene), SOA followed a slope of close to -1 . SOA from $\mathrm{OH}$ oxidation had a higher $\mathrm{H} / \mathrm{C}$ than that from ozonolysis. In ozonolysis, a process with significant hydrogen loss, such as the addition of carbonyl, seemed to play an important role in SOA formation.
In this study, we designed the experiment to study mechanistically the particle formation and growth; therefore, we used two extreme cases: pure $\mathrm{OH}$ oxidation and pure ozonolysis case. We did not do experiments with both $\mathrm{OH}$ and $\mathrm{O}_{3}$. In the atmosphere, where both $\mathrm{OH}$ and $\mathrm{O}_{3}$ are present, products from the reaction of monoterpene with $\mathrm{O}_{3}$ can further react with $\mathrm{OH}$; hence, the chemical composition of aerosol (in terms of elemental composition) may keep evolving continuously. In the atmosphere, both $\mathrm{OH}$ oxidation and ozonolysis of monoterpene are important pathways for particle formation and growth, with their relative importance depending on the specific ambient conditions. 
Appendix A: Additional equations for the relationship of particle mass growth and the reaction rate with $\mathrm{OH}$

In the case of fragmentation, there could be more than one product, $i+_{1}, i+2, i+\mathrm{p}$. Equation (11) in the main text is in a slightly different form.

$\left(\frac{\mathrm{d} m}{\mathrm{~d} t}\right)_{i}=\frac{\mathrm{d} C_{i}^{\mathrm{g}}}{\mathrm{d} t} \cdot m_{\mathrm{t}}\left(\sum_{k=1}^{\mathrm{p}} \frac{1}{C_{i+k}^{0}}-\frac{1}{C_{i}^{0}}\right)$

One can define

$\frac{1}{C_{\mathrm{avg}, i+}^{0}}=\sum_{k=1}^{\mathrm{p}} \frac{1}{C_{i+k}^{0}}$.

Fragmentation usually generates one small volatile molecule and one less volatile molecule (assuming species $P_{i+1}$ ).

$\frac{1}{C_{\mathrm{avg}, i+}^{0}} \approx \frac{1}{C_{i+1}^{0}}$

Thus, $i+{ }_{1}$ can directly correspond to $\mathrm{i}+$ in Eq. (11) in the main text and will not change the format of Eq. (11).

We assume that the molecular weight of $i+$ is similar to that of $i$, i.e., neither functionalization nor fragmentation change the molecular dramatically. In the case of fragmentation, the molecular weight could change significantly if the fragmentation happened in the middle of the carbon bone. In this case we keep the molecular weight of each species.

Equation (14) becomes

$\frac{\mathrm{d} m_{\mathrm{t}}}{\mathrm{d} t}=\sum_{i} R_{\mathrm{OH}, i} m_{\mathrm{t}}\left(\frac{\frac{M_{i+}}{M}}{C_{i+}^{0}}-\frac{\frac{M_{i}}{M}}{C_{i}^{0}}\right)$.

Equation (17) becomes

$\mathrm{GE}_{\mathrm{OH}}(t, i)=\frac{\frac{M_{i+}}{M}}{C_{i+}^{0}}-\frac{\frac{M_{i}}{M}}{C_{i}^{0}}$.

$\mathrm{M}_{i}$ and $\mathrm{M}_{i+}$ can be incorporated in the definition of the overall vapor pressure with a slight change:

$$
\begin{gathered}
\frac{\sum_{i} R_{\mathrm{OH}, i} \cdot \frac{\frac{M_{i+}}{M}}{C_{i+}^{0}}}{\sum_{i}^{R_{\mathrm{OH}, i}}}=\frac{1}{\bar{C}_{i+}^{0}}, \\
\frac{\sum_{i} R_{\mathrm{OH}, i} \cdot \frac{\frac{M_{i+}}{M}}{C_{i}^{0}}}{\sum_{i}^{R_{\mathrm{OH}, i}}}=\frac{1}{\bar{C}_{i}^{0}} .
\end{gathered}
$$




\section{The Supplement related to this article is available online at doi:10.5194/acp-15-991-2015-supplement.}

Acknowledgements. M. J. Wang would like to thank China Scholarship Council for funding the joint $\mathrm{PhD}$ program. The authors would like to thank three anonymous reviewers for helpful comments.

The service charges for this open access publication have been covered by a Research Centre of the Helmholtz Association.

Edited by: N. L. Ng

\section{References}

Aiken, A. C., DeCarlo, P. F., and Jimenez, J. L.: Elemental analysis of organic species with electron ionization highresolution mass spectrometry, Anal. Chem., 79, 8350-8358, doi:10.1021/ac071150w, 2007.

Aiken, A. C., Decarlo, P. F., Kroll, J. H., Worsnop, D. R., Huffman, J. A., Docherty, K. S., Ulbrich, I. M., Mohr, C., Kimmel, J. R., Sueper, D., Sun, Y., Zhang, Q., Trimborn, A., Northway, M., Ziemann, P. J., Canagaratna, M. R., Onasch, T. B., Alfarra, M. R., Prevot, A. S. H., Dommen, J., Duplissy, J., Metzger, A., Baltensperger, U., and Jimenez, J. L.: O / C and OM / OC ratios of primary, secondary, and ambient organic aerosols with highresolution time-of-flight aerosol mass spectrometry, Environ. Sci. Technol., 42, 4478-4485, doi:10.1021/es703009q, 2008.

Allan, J. D., Delia, A. E., Coe, H., Bower, K. N., Alfarra, M. R., Jimenez, J. L., Middlebrook, A. M., Drewnick, F., Onasch, T. B., Canagaratna, M. R., Jayne, J. T., and Worsnop, D. R.: A generalised method for the extraction of chemically resolved mass spectra from aerodyne aerosol mass spectrometer data, J. Aerosol Sci., 35, 909-922, doi:10.1016/j.jaerosci.2004.02.007, 2004.

Andreae, M. O., and Rosenfeld, D.: Aerosol-cloudprecipitation interactions. Part 1 . The nature and sources of cloud-active aerosols, Earth Sci. Rev., 89, 13-41, doi:10.1016/j.earscirev.2008.03.001, 2008.

Apel, E. C., Brauers, T., Koppmann, R., Bandowe, B., Bossmeyer, J., Holzke, C., Tillmann, R., Wahner, A., Wegener, R., Brunner, A., Jocher, M., Ruuskanen, T., Spirig, C., Steigner, D., Steinbrecher, R., Alvarez, E. G., Muller, K., Burrows, J. P., Schade, G., Solomon, S. J., Ladstatter-Weissenmayer, A., Simmonds, P., Young, D., Hopkins, J. R., Lewis, A. C., Legreid, G., Reimann, S., Hansel, A., Wisthaler, A., Blake, R. S., Ellis, A. M., Monks, P. S., and Wyche, K. P.: Intercomparison of oxygenated volatile organic compound measurements at the SAPHIR atmosphere simulation chamber, J. Geophys. Res.-Atmos., 113, D20307, doi:10.1029/2008jd009865, 2008.

Atkinson, R. and Arey, J.: Atmospheric degradation of volatile organic compounds, Chem. Rev., 103, 4605-4638, doi:10.1021/cr0206420, 2003.
Atkinson, R., Baulch, D. L., Cox, R. A., Crowley, J. N., Hampson, R. F., Hynes, R. G., Jenkin, M. E., Rossi, M. J., Troe, J., and IUPAC Subcommittee: Evaluated kinetic and photochemical data for atmospheric chemistry: Volume II - gas phase reactions of organic species, Atmos. Chem. Phys., 6, 3625-4055, doi:10.5194/acp-6-3625-2006, 2006.

Bernard, F., Fedioun, I., Peyroux, F., Quilgars, A., Daele, V., and Mellouki, A.: Thresholds of secondary organic aerosol formation by ozonolysis of monoterpenes measured in a laminar flow aerosol reactor, J. Aerosol Sci., 43, 14-30, doi:10.1016/j.jaerosci.2011.08.005, 2012.

Bohn, B., Rohrer, F., Brauers, T., and Wahner, A.: Actinometric measurements of $\mathrm{NO}_{2}$ photolysis frequencies in the atmosphere simulation chamber SAPHIR, Atmos. Chem. Phys., 5, 493-503, doi:10.5194/acp-5-493-2005, 2005.

Bonn, B. and Moorgat, G. K.: New particle formation during a- and b-pinene oxidation by $\mathrm{O}_{3}, \mathrm{OH}$ and $\mathrm{NO}_{3}$, and the influence of water vapour: particle size distribution studies, Atmos. Chem. Phys., 2, 183-196, doi:10.5194/acp-2-183-2002, 2002.

Burkholder, J. B., Baynard, T., Ravishankara, A. R., and Lovejoy, E. R.: Particle nucleation following the $\mathrm{O}-3$ and $\mathrm{OH}$ initiated oxidation of alpha-pinene and beta-pinene between 278 and 320 K, J. Geophys. Res.-Atmos., 112, D10216, doi:10.1029/2006jd007783, 2007.

Calpini, B., Jeanneret, F., Bourqui, M., Clappier, A., Vajtai, R., and van den Bergh, H.: Direct measurement of the total reaction rate of $\mathrm{OH}$ in the atmosphere, Analusis, 27, 328-336, doi:10.1051/analusis:1999270328, 1999.

Canagaratna, M. R., Jimenez, J. L., Kroll, J. H., Chen, Q., Kessler, S. H., Massoli, P., Hildebrandt Ruiz, L., Fortner, E., Williams, L. R., Wilson, K. R., Surratt, J. D., Donahue, N. M., Jayne, J. T., and Worsnop, D. R.: Elemental ratio measurements of organic compounds using aerosol mass spectrometry: characterization, improved calibration, and implications, Atmos. Chem. Phys., 15, 253-272, doi:10.5194/acp-15-253-2015, 2015.

Carter, W. P. L., Cocker, D. R., Fitz, D. R., Malkina, I. L., Bumiller, K., Sauer, C. G., Pisano, J. T., Bufalino, C., and Song, C.: A new environmental chamber for evaluation of gas-phase chemical mechanisms and secondary aerosol formation, Atmos. Environ., 39, 7768-7788, doi:10.1016/j.atmosenv.2005.08.040, 2005.

Chacon-Madrid, H. J. and Donahue, N. M.: Fragmentation vs. functionalization: chemical aging and organic aerosol formation, Atmos. Chem. Phys., 11, 10553-10563, doi:10.5194/acp11-10553-2011, 2011.

Chacon-Madrid, H. J., Presto, A. A., and Donahue, N. M.: Functionalization vs. fragmentation: n-aldehyde oxidation mechanisms and secondary organic aerosol formation, Phys. Chem. Chem. Phys., 12, 13975-13982, doi:10.1039/c0cp00200c, 2010.

Chhabra, P. S., Ng, N. L., Canagaratna, M. R., Corrigan, A. L., Russell, L. M., Worsnop, D. R., Flagan, R. C., and Seinfeld, J. H.: Elemental composition and oxidation of chamber organic aerosol, Atmos. Chem. Phys., 11, 8827-8845, doi:10.5194/acp-11-88272011, 2011.

Chung, S. H. and Seinfeld, J. H.: Global distribution and climate forcing of carbonaceous aerosols, J. Geophys. Res.-Atmos., 107, 4407, doi:10.1029/2001jd001397, 2002.

Claeys, M., Szmigielski, R., Kourtchev, I., Van der Veken, P., Vermeylen, R., Maenhaut, W., Jaoui, M., Kleindienst, T. E., Lewandowski, M., Offenberg, J. H., and Edney, E. O.: Hydroxy- 
dicarboxylic acids: Markers for secondary organic aerosol from the photooxidation of alpha-pinene, Environ. Sci. Technol., 41, 1628-1634, doi:10.1021/es0620181, 2007.

Compernolle, S., Ceulemans, K., and Müller, J.-F.: EVAPORATION: a new vapour pressure estimation methodfor organic molecules including non-additivity and intramolecular interactions, Atmos. Chem. Phys., 11, 9431-9450, doi:10.5194/acp-119431-2011, 2011.

DeCarlo, P. F., Kimmel, J. R., Trimborn, A., Northway, M. J., Jayne, J. T., Aiken, A. C., Gonin, M., Fuhrer, K., Horvath, T., Docherty, K. S., Worsnop, D. R., and Jimenez, J. L.: Field-deployable, high-resolution, time-of-flight aerosol mass spectrometer, Anal. Chem., 78, 8281-8289, doi:10.1021/ac061249n, 2006.

Donahue, N. M., Henry, K. M., Mentel, T. F., Kiendler-Scharr, A., Spindler, C., Bohn, B., Brauers, T., Dorn, H. P., Fuchs, H., Tillmann, R., Wahner, A., Saathoff, H., Naumann, K. H., Mohler, O., Leisner, T., Muller, L., Reinnig, M. C., Hoffmann, T., Salo, K., Hallquist, M., Frosch, M., Bilde, M., Tritscher, T., Barmet, P., Praplan, A. P., DeCarlo, P. F., Dommen, J., Prevot, A. S. H., and Baltensperger, U.: Aging of biogenic secondary organic aerosol via gas-phase $\mathrm{OH}$ radical reactions, P. Natl. Acad. Sci. USA, 109, 13503-13508, doi:10.1073/pnas.1115186109, 2012.

Eddingsaas, N. C., Loza, C. L., Yee, L. D., Chan, M., Schilling, K. A., Chhabra, P. S., Seinfeld, J. H., and Wennberg, P. O.: $\alpha$-pinene photooxidation under controlled chemical conditions - Part 2: SOA yield and composition in low- and high-NOx environments, Atmos. Chem. Phys., 12, 7413-7427, doi:10.5194/acp-12-74132012, 2012.

Ehn, M., Kleist, E., Junninen, H., Petäjä, T., Lönn, G., Schobesberger, S., Dal Maso, M., Trimborn, A., Kulmala, M., Worsnop, D. R., Wahner, A., Wildt, J., and Mentel, Th. F.: Gas phase formation of extremely oxidized pinene reaction products in chamber and ambient air, Atmos. Chem. Phys., 12, 5113-5127, doi:10.5194/acp-12-5113-2012, 2012.

Ehn, M., Thornton, J. A., Kleist, E., Sipila, M., Junninen, H., Pullinen, I., Springer, M., Rubach, F., Tillmann, R., Lee, B., LopezHilfiker, F., Andres, S., Acir, I.-H., Rissanen, M., Jokinen, T., Schobesberger, S., Kangasluoma, J., Kontkanen, J., Nieminen, T., Kurten, T., Nielsen, L. B., Jorgensen, S., Kjaergaard, H. G., Canagaratna, M., Maso, M. D., Berndt, T., Petaja, T., Wahner, A., Kerminen, V.-M., Kulmala, M., Worsnop, D. R., Wildt, J., and Mentel, T. F.: A large source of low-volatility secondary organic aerosol, Nature, 506, 476-479, doi:10.1038/nature13032, 2014.

Emanuelsson, E. U., Hallquist, M., Kristensen, K., Glasius, M., Bohn, B., Fuchs, H., Kammer, B., Kiendler-Scharr, A., Nehr, S., Rubach, F., Tillmann, R., Wahner, A., Wu, H.-C., and Mentel, Th. F.: Formation of anthropogenic secondary organic aerosol (SOA) and its influence on biogenic SOA properties, Atmos. Chem. Phys., 13, 2837-2855, doi:10.5194/acp-13-2837-2013, 2013.

Fry, J. L., Kiendler-Scharr, A., Rollins, A. W., Brauers, T., Brown, S. S., Dorn, H.-P., Dubé, W. P., Fuchs, H., Mensah, A., Rohrer, F., Tillmann, R., Wahner, A., Wooldridge, P. J., and Cohen, R. C.: SOA from limonene: role of $\mathrm{NO}_{3}$ in its generation and degradation, Atmos. Chem. Phys., 11, 3879-3894, doi:10.5194/acp-113879-2011, 2011.

Fuchs, H., Hofzumahaus, A., Rohrer, F., Bohn, B., Brauers, T., Dorn, H. P., Haeseler, R., Holland, F., Kaminski, M., Li, X., Lu, K., Nehr, S., Tillmann, R., Wegener, R., and Wahner,
A.: Experimental evidence for efficient hydroxyl radical regeneration in isoprene oxidation, Nat. Geosci., 6, 1023-1026, doi:10.1038/ngeo1964, 2013.

Gill, K. J. and Hites, R. A.: Rate constants for the gas-phase reactions of the hydroxyl radical with isoprene, alpha- and betapinene, and limonene as a function of temperature, J. Phys. Chem. A, 106, 2538-2544, doi:10.1021/jp013532q, 2002.

Goldstein, A. H. and Galbally, I. E.: Known and unexplored organic constituents in the earth's atmosphere, Environ. Sci. Technol., 41, 1514-1521, doi:10.1021/es072476p, 2007.

Griffin, R. J., Cocker, D. R., Flagan, R. C., and Seinfeld, J. H.: Organic aerosol formation from the oxidation of biogenic hydrocarbons, J. Geophys. Res.-Atmos., 104, 3555-3567, doi:10.1029/1998jd100049, 1999.

Guenther, A., Hewitt, C. N., Erickson, D., Fall, R., Geron, C., Graedel, T., Harley, P., Klinger, L., Lerdau, M., McKay, W. A., Pierce, T., Scholes, B., Steinbrecher, R., Tallamraju, R., Taylor, J., and Zimmerman, P.: A global-model of natural volatile organic-compound emissions, J. Geophys. Res.-Atmos., 100, 8873-8892, doi:10.1029/94jd02950, 1995.

Guenther, A. B., Jiang, X., Heald, C. L., Sakulyanontvittaya, T., Duhl, T., Emmons, L. K., and Wang, X.: The Model of Emissions of Gases and Aerosols from Nature version 2.1 (MEGAN2.1): an extended and updated framework for modeling biogenic emissions, Geosci. Model Dev., 5, 1471-1492, doi:10.5194/gmd-51471-2012, 2012.

Hallquist, M., Wenger, J. C., Baltensperger, U., Rudich, Y., Simpson, D., Claeys, M., Dommen, J., Donahue, N. M., George, C., Goldstein, A. H., Hamilton, J. F., Herrmann, H., Hoffmann, T., Iinuma, Y., Jang, M., Jenkin, M. E., Jimenez, J. L., Kiendler-Scharr, A., Maenhaut, W., McFiggans, G., Mentel, Th. F., Monod, A., Prévôt, A. S. H., Seinfeld, J. H., Surratt, J. D., Szmigielski, R., and Wildt, J.: The formation, properties and impact of secondary organic aerosol: current and emerging issues, Atmos. Chem. Phys., 9, 5155-5236, doi:10.5194/acp-9-51552009, 2009.

Hanke, M., Uecker, J., Reiner, T., and Arnold, F.: Atmospheric peroxy radicals: ROXMAS, a new mass-spectrometric methodology for speciated measurements of $\mathrm{HO}_{2}$ and Sigma $\mathrm{RO} 2$ and first results, Int. J. Mass Spectrom., 213, 91-99, doi:10.1016/s13873806(01)00548-6, 2002.

Hao, L. Q., Yli-Pirilä, P., Tiitta, P., Romakkaniemi, S., Vaattovaara, P., Kajos, M. K., Rinne, J., Heijari, J., Kortelainen, A., Miettinen, P., Kroll, J. H., Holopainen, J. K., Smith, J. N., Joutsensaari, J., Kulmala, M., Worsnop, D. R., and Laaksonen, A.: New particle formation from the oxidation of direct emissions of pine seedlings, Atmos. Chem. Phys., 9, 8121-8137, doi:10.5194/acp9-8121-2009, 2009.

Häseler, R., Brauers, T., Holland, F., and Wahner, A.: Development and application of a new mobile LOPAP instrument for the measurement of HONO altitude profiles in the planetary boundary layer, Atmos. Meas. Tech. Discuss., 2, 2027-2054, doi:10.5194/amtd-2-2027-2009, 2009.

Heald, C. L., Kroll, J. H., Jimenez, J. L., Docherty, K. S., DeCarlo, P. F., Aiken, A. C., Chen, Q., Martin, S. T., Farmer, D. K., and Artaxo, P.: A simplified description of the evolution of organic aerosol composition in the atmosphere, Geophys. Res. Lett., 37, L08803, doi:10.1029/2010g1042737, 2010. 
Henry, K. M., Lohaus, T., and Donahue, N. M.: Organic Aerosol Yields from alpha-Pinene Oxidation: Bridging the Gap between First-Generation Yields and Aging Chemistry, Environ. Sci. Technol., 46, 12347-12354, doi:10.1021/es302060y, 2012.

Hoffmann, T., Odum, J. R., Bowman, F., Collins, D., Klockow, D., Flagan, R. C., and Seinfeld, J. H.: Formation of organic aerosols from the oxidation of biogenic hydrocarbons, J. Atoms. Chem., 26, 189-222, doi:10.1023/a:1005734301837, 1997.

Hofzumahaus, A., Rohrer, F., Lu, K. D., Bohn, B., Brauers, T., Chang, C. C., Fuchs, H., Holland, F., Kita, K., Kondo, Y., Li, X., Lou, S. R., Shao, M., Zeng, L. M., Wahner, A., and Zhang, Y. H.: Amplified Trace Gas Removal in the Troposphere, Science, 324, 1702-1704, doi:10.1126/science.1164566, 2009.

Iinuma, Y., Boge, O., Miao, Y., Sierau, B., Gnauk, T., and Herrmann, H.: Laboratory studies on secondary organic aerosol formation from terpenes, Faraday Discuss., 130, 279-294, doi:10.1039/b502160j, 2005.

Jaoui, M., Kleindienst, T. E., Lewandowski, M., Offenberg, J. H., and Edney, E. O.: Identification and quantification of aerosol polar oxygenated compounds bearing carboxylic or hydroxyl groups. 2. Organic tracer compounds from monoterpenes, Environ. Sci. Technol., 39, 5661-5673, doi:10.1021/es048111b, 2005.

Jimenez, J. L., Canagaratna, M. R., Donahue, N. M., Prevot, A. S. H., Zhang, Q., Kroll, J. H., DeCarlo, P. F., Allan, J. D., Coe, H., Ng, N. L., Aiken, A. C., Docherty, K. S., Ulbrich, I. M., Grieshop, A. P., Robinson, A. L., Duplissy, J., Smith, J. D., Wilson, K. R., Lanz, V. A., Hueglin, C., Sun, Y. L., Tian, J., Laaksonen, A., Raatikainen, T., Rautiainen, J., Vaattovaara, P., Ehn, M., Kulmala, M., Tomlinson, J. M., Collins, D. R., Cubison, M. J., Dunlea, E. J., Huffman, J. A., Onasch, T. B., Alfarra, M. R., Williams, P. I., Bower, K., Kondo, Y., Schneider, J., Drewnick, F., Borrmann, S., Weimer, S., Demerjian, K., Salcedo, D., Cottrell, L., Griffin, R., Takami, A., Miyoshi, T., Hatakeyama, S., Shimono, A., Sun, J. Y., Zhang, Y. M., Dzepina, K., Kimmel, J. R., Sueper, D., Jayne, J. T., Herndon, S. C., Trimborn, A. M., Williams, L. R., Wood, E. C., Middlebrook, A. M., Kolb, C. E., Baltensperger, U., and Worsnop, D. R.: Evolution of Organic Aerosols in the Atmosphere, Science, 326, 1525-1529, doi:10.1126/science.1180353, 2009.

Jordan, A., Haidacher, S., Hanel, G., Hartungen, E., Mark, L., Seehauser, H., Schottkowsky, R., Sulzer, P., and Mark, T. D.: A high resolution and high sensitivity proton-transfer-reaction time-offlight mass spectrometer (PTR-TOF-MS), Int. J. Mass Spectrom., 286, 122-128, doi:10.1016/j.ijms.2009.07.005, 2009.

Kaminiski, M.: Untersuchung des photochemischen Terpenoidabbaus in der Atmosphärensimulationskammer SAPHIR, PhD, Institut für Physikalische Chemie, Universität zu Köln, Jülich, 2014.

Kanakidou, M., Seinfeld, J. H., Pandis, S. N., Barnes, I., Dentener, F. J., Facchini, M. C., Van Dingenen, R., Ervens, B., Nenes, A., Nielsen, C. J., Swietlicki, E., Putaud, J. P., Balkanski, Y., Fuzzi, S., Horth, J., Moortgat, G. K., Winterhalter, R., Myhre, C. E. L., Tsigaridis, K., Vignati, E., Stephanou, E. G., and Wilson, J.: Organic aerosol and global climate modelling: a review, Atmos. Chem. Phys., 5, 1053-1123, doi:10.5194/acp-5-1053-2005, 2005.

Kiendler-Scharr, A., Wildt, J., Dal Maso, M., Hohaus, T., Kleist, E., Mentel, T. F., Tillmann, R., Uerlings, R., Schurr, U., and Wahner,
A.: New particle formation in forests inhibited by isoprene emissions, Nature, 461, 381-384, doi:10.1038/nature08292, 2009a.

Kiendler-Scharr, A., Zhang, Q., Hohaus, T., Kleist, E., Mensah, A., Mentel, T. F., Spindler, C., Uerlings, R., Tillmann, R., and Wildt, J.: Aerosol Mass Spectrometric Features of Biogenic SOA: Observations from a Plant Chamber and in Rural Atmospheric Environments, Environ. Sci. Technol., 43, 8166-8172, doi:10.1021/es901420b, 2009b.

Kiendler-Scharr, A., Andres, S., Bachner, M., Behnke, K., Broch, S., Hofzumahaus, A., Holland, F., Kleist, E., Mentel, T. F., Rubach, F., Springer, M., Steitz, B., Tillmann, R., Wahner, A., Schnitzler, J.-P., and Wildt, J.: Isoprene in poplar emissions: effects on new particle formation and $\mathrm{OH}$ concentrations, Atmos. Chem. Phys., 12, 1021-1030, doi:10.5194/acp-12-1021-2012, 2012.

Kim, H., Barkey, B., and Paulson, S. E.: Real Refractive Indices and Formation Yields of Secondary Organic Aerosol Generated from Photooxidation of Limonene and alpha-Pinene: The Effect of the HC/NOx Ratio, J. Phys. Chem. A, 116, 6059-6067, doi:10.1021/jp301302z, 2012.

Kim, S., Wolfe, G. M., Mauldin, L., Cantrell, C., Guenther, A., Karl, T., Turnipseed, A., Greenberg, J., Hall, S. R., Ullmann, K., Apel, E., Hornbrook, R., Kajii, Y., Nakashima, Y., Keutsch, F. N., DiGangi, J. P., Henry, S. B., Kaser, L., Schnitzhofer, R., Graus, M., Hansel, A., Zheng, W., and Flocke, F. F.: Evaluation of HOx sources and cycling using measurement-constrained model calculations in a 2-methyl-3-butene-2-ol (MBO) and monoterpene (MT) dominated ecosystem, Atmos. Chem. Phys., 13, 20312044, doi:10.5194/acp-13-2031-2013, 2013.

Kristensen, K., Cui, T., Zhang, H., Gold, A., Glasius, M., and Surratt, J. D.: Dimers in $\alpha$-pinene secondary organic aerosol: effect of hydroxyl radical, ozone, relative humidity and aerosol acidity, Atmos. Chem. Phys., 14, 4201-4218, doi:10.5194/acp-14-42012014, 2014.

Kroll, J. H. and Seinfeld, J. H.: Chemistry of secondary organic aerosol: Formation and evolution of low-volatility organics in the atmosphere, Atmos. Environ., 42, 3593-3624, doi:10.1016/j.atmosenv.2008.01.003, 2008.

Kroll, J. H., Smith, J. D., Che, D. L., Kessler, S. H., Worsnop, D. R., and Wilson, K. R.: Measurement of fragmentation and functionalization pathways in the heterogeneous oxidation of oxidized organic aerosol, Phys. Chem. Chem. Phys., 11, 8005-8014, doi:10.1039/b905289e, 2009.

Lee, A., Goldstein, A. H., Keywood, M. D., Gao, S., Varutbangkul, V., Bahreini, R., Ng, N. L., Flagan, R. C., and Seinfeld, J. H.: Gas-phase products and secondary aerosol yields from the ozonolysis of ten different terpenes, J. Geophys. Res.-Atmos., 111, D07302, doi:10.1029/2005jd006437, 2006.

Lou, S., Holland, F., Rohrer, F., Lu, K., Bohn, B., Brauers, T., Chang, C.C., Fuchs, H., Häseler, R., Kita, K., Kondo, Y., Li, X., Shao, M., Zeng, L., Wahner, A., Zhang, Y., Wang, W., and Hofzumahaus, A.: Atmospheric $\mathrm{OH}$ reactivities in the Pearl River Delta - China in summer 2006: measurement and model results, Atmos. Chem. Phys., 10, 11243-11260, doi:10.5194/acp-10-11243-2010, 2010.

Loza, C. L., Craven, J. S., Yee, L. D., Coggon, M. M., Schwantes, R. H., Shiraiwa, M., Zhang, X., Schilling, K. A., Ng, N. L., Canagaratna, M. R., Ziemann, P. J., Flagan, R. C., and Seinfeld, J. H.: Secondary organic aerosol yields of 12-carbon alkanes, 
Atmos. Chem. Phys., 14, 1423-1439, doi:10.5194/acp-14-14232014, 2014

Ma, Y., Russell, A. T., and Marston, G.: Mechanisms for the formation of secondary organic aerosol components from the gasphase ozonolysis of alpha-pinene, Phys. Chem. Chem. Phys., 10, 4294-4312, doi:10.1039/b803283a, 2008.

Matsunaga, A. and Ziemann, P. J.: Gas-Wall Partitioning of Organic Compounds in a Teflon Film Chamber and Potential Effects on Reaction Product and Aerosol Yield Measurements, Aerosol Sci. Technol., 44, 881-892, doi:10.1080/02786826.2010.501044, 2010.

Mentel, Th. F., Wildt, J., Kiendler-Scharr, A., Kleist, E., Tillmann, R., Dal Maso, M., Fisseha, R., Hohaus, Th., Spahn, H., Uerlings, R., Wegener, R., Griffiths, P. T., Dinar, E., Rudich, Y., and Wahner, A.: Photochemical production of aerosols from real plant emissions, Atmos. Chem. Phys., 9, 4387-4406, doi:10.5194/acp9-4387-2009, 2009.

Mihelcic, D., Holland, F., Hofzumahaus, A., Hoppe, L., Konrad, S., Musgen, P., Patz, H. W., Schafer, H. J., Schmitz, T., VolzThomas, A., Bachmann, K., Schlomski, S., Platt, U., Geyer, A., Alicke, B., and Moortgat, G. K.: Peroxy radicals during BERLIOZ at Pabstthum: Measurements, radical budgets and ozone production, J. Geophys. Res.-Atmos., 108, 8254, doi:10.1029/2001jd001014, 2003.

Müller, L., Reinnig, M.-C., Naumann, K. H., Saathoff, H., Mentel, T. F., Donahue, N. M., and Hoffmann, T.: Formation of 3-methyl1,2,3-butanetricarboxylic acid via gas phase oxidation of pinonic acid - a mass spectrometric study of SOA aging, Atmos. Chem. Phys., 12, 1483-1496, doi:10.5194/acp-12-1483-2012, 2012.

Ng, N. L., Kroll, J. H., Keywood, M. D., Bahreini, R., Varutbangkul, V., Flagan, R. C., Seinfeld, J. H., Lee, A., and Goldstein, A. H.: Contribution of first- versus second-generation products to secondary organic aerosols formed in the oxidation of biogenic hydrocarbons, Environ. Sci. Technol., 40, 2283-2297, doi:10.1021/es052269u, 2006.

Ng, N. L., Chhabra, P. S., Chan, A. W. H., Surratt, J. D., Kroll, J. H., Kwan, A. J., McCabe, D. C., Wennberg, P. O., Sorooshian, A., Murphy, S. M., Dalleska, N. F., Flagan, R. C., and Seinfeld, J. H.: Effect of $\mathrm{NO}_{\mathrm{x}}$ level on secondary organic aerosol (SOA) formation from the photooxidation of terpenes, Atmos. Chem. Phys., 7, 5159-5174, doi:10.5194/acp-7-5159-2007, 2007.

Ng, N. L., Canagaratna, M. R., Zhang, Q., Jimenez, J. L., Tian, J., Ulbrich, I. M., Kroll, J. H., Docherty, K. S., Chhabra, P. S., Bahreini, R., Murphy, S. M., Seinfeld, J. H., Hildebrandt, L., Donahue, N. M., DeCarlo, P. F., Lanz, V. A., Prévôt, A. S. H., Dinar, E., Rudich, Y., and Worsnop, D. R.: Organic aerosol components observed in Northern Hemispheric datasets from Aerosol Mass Spectrometry, Atmos. Chem. Phys., 10, 46254641, doi:10.5194/acp-10-4625-2010, 2010.

Ng, N. L., Canagaratna, M. R., Jimenez, J. L., Chhabra, P. S., Seinfeld, J. H., and Worsnop, D. R.: Changes in organic aerosol composition with aging inferred from aerosol mass spectra, Atmos. Chem. Phys., 11, 6465-6474, doi:10.5194/acp-11-64652011, 2011.

Odum, J. R., Hoffmann, T., Bowman, F., Collins, D., Flagan, R. C., and Seinfeld, J. H.: Gas/particle partitioning and secondary organic aerosol yields, Environ. Sci. Technol., 30, 2580-2585, doi:10.1021/es950943+, 1996.
Ortega, I. K., Suni, T., Boy, M., Grönholm, T., Manninen, H. E., Nieminen, T., Ehn, M., Junninen, H., Hakola, H., Hellén, H., Valmari, T., Arvela, H., Zegelin, S., Hughes, D., Kitchen, M., Cleugh, H., Worsnop, D. R., Kulmala, M., and Kerminen, V.-M.: New insights into nocturnal nucleation, Atmos. Chem. Phys., 12, 4297-4312, doi:10.5194/acp-12-4297-2012, 2012.

Pankow, J. F.: An absorption-model of the gas aerosol partitioning involved in the formation of secondary organic aerosol, Atmos. Environ., 28, 189-193, doi:10.1016/1352-2310(94)900949, 1994

Pathak, R. K., Stanier, C. O., Donahue, N. M., and Pandis, S. N.: Ozonolysis of alpha-pinene at atmospherically relevant concentrations: Temperature dependence of aerosol mass fractions (yields), J. Geophys. Res.-Atmos., 112, D03201, doi:10.1029/2006jd007436, 2007.

Pathak, R., Donahue, N. M., and Pandis, S. N.: Ozonolysis of beta-pinene: Temperature dependence of secondary organic aerosol mass fraction, Environ. Sci. Technol., 42, 5081-5086, doi:10.1021/es070721z, 2008.

Pfaffenberger, L., Barmet, P., Slowik, J. G., Praplan, A. P., Dommen, J., Prévôt, A. S. H., and Baltensperger, U.: The link between organic aerosol mass loading and degree of oxygenation: an ?pinene photooxidation study, Atmos. Chem. Phys., 13, 64936506, doi:10.5194/acp-13-6493-2013, 2013.

Pierce, J. R., Engelhart, G. J., Hildebrandt, L., Weitkamp, E. A., Pathak, R. K., Donahue, N. M., Robinson, A. L., Adams, P. J., and Pandis, S. N.: Constraining particle evolution from wall losses, coagulation, and condensation-evaporation in smogchamber experiments: Optimal estimation based on size distribution measurements, Aerosol Sci. Technol., 42, 1001-1015, doi:10.1080/02786820802389251, 2008.

Presto, A. A. and Donahue, N. M.: Investigation of alphapinene plus ozone secondary organic aerosol formation at low total aerosol mass, Environ. Sci. Technol., 40, 3536-3543, doi:10.1021/es052203z, 2006.

Presto, A. A., Hartz, K. E. H., and Donahue, N. M.: Secondary organic aerosol production from terpene ozonolysis. 2. Effect of NOx concentration, Environ. Sci. Technol., 39, 7046-7054, doi:10.1021/es050400s, 2005.

Renbaum-Wolff, L., Grayson, J. W., Bateman, A. P., Kuwata, M., Sellier, M., Murray, B. J., Shilling, J. E., Martin, S. T., and Bertram, A. K.: Viscosity of alpha-pinene secondary organic material and implications for particle growth and reactivity, P. Natl. Acad. Sci. USA, 110, 8014-8019, doi:10.1073/pnas.1219548110, 2013.

Rohrer, F., Bohn, B., Brauers, T., Brüning, D., Johnen, F.-J., Wahner, A., and Kleffmann, J.: Characterisation of the photolytic HONO-source in the atmosphere simulation chamber SAPHIR, Atmos. Chem. Phys., 5, 2189-2201, doi:10.5194/acp-5-21892005, 2005.

Saathoff, H., Naumann, K.-H., Möhler, O., Jonsson, Å. M., Hallquist, M., Kiendler-Scharr, A., Mentel, Th. F., Tillmann, R., and Schurath, U.: Temperature dependence of yields of secondary organic aerosols from the ozonolysis of $\alpha$-pinene and limonene, Atmos. Chem. Phys., 9, 1551-1577, doi:10.5194/acp-9-15512009, 2009. 
Sadanaga, Y., Yoshino, A., Watanabe, K., Yoshioka, A., Wakazono, Y., Kanaya, Y., and Kajii, Y.: Development of a measurement system of $\mathrm{OH}$ reactivity in the atmosphere by using a laserinduced pump and probe technique, Rev. Sci. Instrum., 75, 26482655, doi:10.1063/1.1775311, 2004.

Salo, K., Hallquist, M., Jonsson, ̊. M., Saathoff, H., Naumann, K.H., Spindler, C., Tillmann, R., Fuchs, H., Bohn, B., Rubach, F., Mentel, Th. F., Müller, L., Reinnig, M., Hoffmann, T., and Donahue, N. M.: Volatility of secondary organic aerosol during $\mathrm{OH}$ radical induced ageing, Atmos. Chem. Phys., 11, 11055-11067, doi:10.5194/acp-11-11055-2011, 2011.

Shilling, J. E., Chen, Q., King, S. M., Rosenoern, T., Kroll, J. H., Worsnop, D. R., McKinney, K. A., and Martin, S. T.: Particle mass yield in secondary organic aerosol formed by the dark ozonolysis of $\alpha$-pinene, Atmos. Chem. Phys., 8, 2073-2088, doi:10.5194/acp-8-2073-2008, 2008.

Shilling, J. E., Chen, Q., King, S. M., Rosenoern, T., Kroll, J. H., Worsnop, D. R., DeCarlo, P. F., Aiken, A. C., Sueper, D., Jimenez, J. L., and Martin, S. T.: Loading-dependent elemental composition of $\alpha$-pinene SOA particles, Atmos. Chem. Phys., 9, 771-782, doi:10.5194/acp-9-771-2009, 2009.

Shiraiwa, M. and Seinfeld, J. H.: Equilibration timescale of atmospheric secondary organic aerosol partitioning, Geophys. Res. Lett., 39, L24801, doi:10.1029/2012gl054008, 2012.

Spracklen, D. V., Jimenez, J. L., Carslaw, K. S., Worsnop, D. R., Evans, M. J., Mann, G. W., Zhang, Q., Canagaratna, M. R., Allan, J., Coe, H., McFiggans, G., Rap, A., and Forster, P.: Aerosol mass spectrometer constraint on the global secondary organic aerosol budget, Atmos. Chem. Phys., 11, 12109-12136, doi:10.5194/acp-11-12109-2011, 2011.

Szmigielski, R., Surratt, J. D., Gomez-Gonzalez, Y., Van der Veken, P., Kourtchev, I., Vermeylen, R., Blockhuys, F., Jaoui, M., Kleindienst, T. E., Lewandowski, M., Offenberg, J. H., Edney, E. O., Seinfeld, J. H., Maenhaut, W., and Claeys, M.: 3-methyl1,2,3-butanetricarboxylic acid: An atmospheric tracer for terpene secondary organic aerosol, Geophys. Res. Lett., 34, L24811, doi:10.1029/2007g1031338, 2007.

Tillmann, R., Hallquist, M., Jonsson, Å. M., Kiendler-Scharr, A., Saathoff, H., Iinuma, Y., and Mentel, Th. F.: Influence of relative humidity and temperature on the production of pinonaldehyde and $\mathrm{OH}$ radicals from the ozonolysis of $\alpha$-pinene, Atmos. Chem. Phys., 10, 7057-7072, doi:10.5194/acp-10-7057-2010, 2010.
Vaden, T. D., Imre, D., Beranek, J., Shrivastava, M., and Zelenyuk, A.: Evaporation kinetics and phase of laboratory and ambient secondary organic aerosol, P. Natl. Acad. Sci. USA, 108, 2190 2195, doi:10.1073/pnas.1013391108, 2011.

Virtanen, A., Joutsensaari, J., Koop, T., Kannosto, J., Yli-Pirila, P., Leskinen, J., Makela, J. M., Holopainen, J. K., Poeschl, U., Kulmala, M., Worsnop, D. R., and Laaksonen, A.: An amorphous solid state of biogenic secondary organic aerosol particles, Nature, 467, 824-827, doi:10.1038/nature09455, 2010.

Whalley, L. K., Edwards, P. M., Furneaux, K. L., Goddard, A., Ingham, T., Evans, M. J., Stone, D., Hopkins, J. R., Jones, C. E., Karunaharan, A., Lee, J. D., Lewis, A. C., Monks, P. S., Moller, S. J., and Heard, D. E.: Quantifying the magnitude of a missing hydroxyl radical source in a tropical rainforest, Atmos. Chem. Phys., 11, 7223-7233, doi:10.5194/acp-11-7223-2011, 2011.

Yu, J. Z., Cocker, D. R., Griffin, R. J., Flagan, R. C., and Seinfeld, J. H.: Gas-phase ozone oxidation of monoterpenes: Gaseous and particulate products, J. Atoms. Chem., 34, 207-258, doi:10.1023/a:1006254930583, 1999.

Zhang, J. Y., Hartz, K. E. H., Pandis, S. N., and Donahue, N. M.: Secondary organic aerosol formation from limonene ozonolysis: Homogeneous and heterogeneous influences as a function of $\mathrm{NO}_{\mathrm{x}}$, J. Phys. Chem. A, 110, 11053-11063, doi:10.1021/jp062836f, 2006.

Zhang, Q., Jimenez, J. L., Canagaratna, M. R., Ulbrich, I. M., Ng, N. L., Worsnop, D. R., and Sun, Y. L.: Understanding atmospheric organic aerosols via factor analysis of aerosol mass spectrometry: a review, Anal. Bioanal. Chem., 401, 3045-3067, doi:10.1007/s00216-011-5355-y, 2011.

Zhang, X., Pandis, S. N., and Seinfeld, J. H.: Diffusion-Limited Versus Quasi-Equilibrium Aerosol Growth, Aerosol Sci. Technol., 46, 874-885, doi:10.1080/02786826.2012.679344, 2012.

Zhang, X., Cappa, C. D., Jathar, S. H., McVay, R. C., Ensberg, J. J., Kleeman, M. J., and Seinfeld, J. H.: Influence of vapor wall loss in laboratory chambers on yields of secondary organic aerosol, P. Natl. Acad. Sci. USA, 111, 5802-5807, doi:10.1073/pnas.1404727111, 2014.

Ziemann, P. J. and Atkinson, R.: Kinetics, products, and mechanisms of secondary organic aerosol formation, Chem. Soc. Rev., 41, 6582-6605, doi:10.1039/c2cs35122f, 2012. 